Article

\title{
Diversity and Pathogenicity of Diaporthe Species Revealed from a Survey of Blueberry Orchards in Portugal
}

\author{
Sandra Hilário (D), Liliana Santos (D) and Artur Alves*(D) \\ Centre for Environmental and Marine Studies (CESAM), Department of Biology, Campus Universitário de \\ Santiago, University of Aveiro, 3810-193 Aveiro, Portugal; sandra.hilario@ua.pt (S.H.); ltsantos@ua.pt (L.S.) \\ * Correspondence: artur.alves@ua.pt
}

check for updates

Citation: Hilário, S.; Santos, L.;

Alves, A. Diversity and Pathogenicity of Diaporthe Species Revealed from a Survey of Blueberry Orchards in Portugal. Agriculture 2021, 11, 1271. https://doi.org/10.3390/ agriculture11121271

Academic Editor: Roy Kennedy

Received: 5 November 2021

Accepted: 11 December 2021

Published: 14 December 2021

Publisher's Note: MDPI stays neutral with regard to jurisdictional claims in published maps and institutional affiliations.

Copyright: (c) 2021 by the authors. Licensee MDPI, Basel, Switzerland. This article is an open access article distributed under the terms and conditions of the Creative Commons Attribution (CC BY) license (https:// creativecommons.org/licenses/by/ $4.0 /)$.

\begin{abstract}
Blueberries (Vaccinium corymbosum) are widely cultivated worldwide and largely consumed due to their known antioxidant and medicinal properties. Although Diaporthe species have been documented in Portugal as causal agents of blueberry twig blight and dieback, there is still scarce information on the species that cause these symptoms. Moreover, Diaporthe vaccinii, recently synonymized with $D$. eres, has been considered a concern to blueberry production worldwide. However, the current knowledge about its impact on blueberries remains unclear. The diversity of Diaporthe species associated with diseased blueberry plants were assessed through a national survey. A multilocus sequence analysis of the rDNA internal transcribed spacer (ITS) region, the translation elongation factor 1-alpha (tef1- $\alpha), \beta$-tubulin (tub2), calmodulin (cal) and histone 3 (his3) genes unveiled the presence of Diaporthe ambigua, D. amygdali, D. crousii, D. foeniculina, D. hybrida, D. leucospermi, D. malorum and D. rudis. Moreover, all species were fully characterized based on a detailed morphological description. Diaporthe amygdali, D. hybrida, D. leucospermi and D. malorum are reported for the first time on diseased blueberries in Portugal. Results show that D. eres exhibited a high level of intraspecific variability within isolates, given that the strain CBS 160.32 might be a minor pathogen on blueberry plants, whereas CAA829 was revealed to be the most aggressive. Overall, this study also demonstrates that Diaporthe amygdali and D. eres may be two of the most aggressive species to blueberry plants. This study improves our understanding of the Diaporthe species and it's causing of dieback and twig blight on Portuguese blueberry orchards. Additionally, the identification of these pathogens represents crucial information for blueberry producers to apply appropriate phytosanitary measures, as well as offering new insights into the potential pathogenicity of $D$. eres on this host.
\end{abstract}

Keywords: Diaporthaceae; dieback; pathogens; phylogeny; twig blight; Vaccinium corymbosum

\section{Introduction}

The genus Vaccinium L. includes nearly 450 species of perennial shrubs belonging to the family Ericaceae which have adapted to several climates [1]. The species Vaccinium corymbosum (known as northern highbush blueberry) is a small-fruit crop, native to North America and commercially cultivated in Europe [2]. Due to the recognized high nutritional and medicinal value of fruits [3,4], blueberry production has been rapidly increasing worldwide.

In the last 10 years the production of this crop in Portugal has increased substantially. Although production initiated intensively only in 2011 with a yield of 700 tons and a cultivated area of 75 ha, in 2019 the country was ranked as the 9th largest producer worldwide [5], with a production of 15,418 tons, occupying a total area of 2490 ha [6], making it a highly profitable crop to the economy of the country. However, due to the spread of blueberry plant material across continents, it is expected that several fungal pathogens may affect blueberry orchards, given their entry into new habitats [7]. Some of these pathogens, such as members of Botryosphaeriaceae, Pestalotiopsis sensu lato and Diaporthe can cause twig blight, stem cankers and dieback on blueberry plants [8-10].

The genus Diaporthe encompasses endophytes, saprobes and plant pathogens associated with a wide variety of agricultural crops, ornamental plants, and forest trees [11-16]. 
Members of this genus were previously found to colonize blueberry tissues as latent pathogens or endophytes [8] and as pathogens causing numerous diseases on this crop such as apical necrosis of twigs and stems, cankers, necrosis of the vascular tissues, wilting of leaves, and leaf spots $[7,17,18]$. These symptoms have been associated with an assemblage of species comprising D. ambigua, D. amygdali, D. australafricana, D. baccae, D. crousii, D. eres, $D$. foeniculina, D. oxe, D. passiflorae, D. phillipsii, D. rossmaniae, D. rudis, and D. vaccinii (syn. D. eres) $[2,8,17,19-21]$.

Diaporthe vaccinii, formerly known as Phomopsis vaccinii, is native to North America [22] and it is recognized as a host-specific species on Vaccinium spp., causing severe losses to blueberry production worldwide $[2,8]$. Concerns about the damaging impacts of this pathogen on blueberry production led the European Food Safety Authority (EFSA) to recommend D. vaccinii as a quarantine pathogen for the European Union (Regulation (EU) 2016/2031 of 26 October 2016). Although D. vaccinii has been reported on blueberry plants in South America [17], North America [19,23], Europe [2,7,24] and Asia [18], the current knowledge about its pathogenicity on blueberries was barely explored. However, the most recent EU Regulation of 29 November 2919 (2019/2072), has no longer included D. vaccinii into the list of EU quarantine pests. Moreover, to clarify the species boundaries of the Diaporthe eres complex, Hilário et al. [20] implemented the Genealogical Phylogenetic Species Recognition principle (GCPSR) and the coalescent-based model Poisson Tree Processes (PTPs) and considered D. vaccinii to be a synonym of D. eres.

Nevertheless, despite the alleged presence of $D$. vaccinii in the North of Portugal based on the symptoms observed in the field [25], this species was not found in a recent survey carried out in one of the major blueberry productions in the country [8]. Given that species identification is essential to develop appropriate control measures, the focus of this study was the implementation of a large survey on Vaccinium corymbosum plantations across the country, aiming to understand the diversity and distribution of Diaporthe species associated with blueberry plants showing dieback and twig blight symptoms, as well as their pathogenic potential to different blueberry cultivars widely planted in the country.

\section{Materials and Methods}

\subsection{Sampling and Fungal Isolates}

Sampling of plant material was carried out between April and August of 2019 in 12 Portuguese blueberry orchards (Table 1): Braga, Porto, Aveiro, Viseu, Castelo Branco and Santarém.

Plants from cultivars 'Duke', 'Ozarkblue', 'Aurora', 'Legacy', 'O'Neal', 'Liberty', 'Gupton', 'Bluecrop', 'Early Blue' and 'New Hanover' corresponding to an area of 31 ha were examined. Nearly $0.5 \%$ of plants from each plantation were checked for disease symptoms such as twig blight, stem cankers, and wilting and necrotic leaves in the apex of the plant. From the 531 plants inspected, only 95 showing these symptoms were collected. The samples were transported to the Fungal and Plant Biology Lab at University of Aveiro in paper bags, to prevent moisture, within 4-6 h. After arrival, one $10-30 \mathrm{~cm}$ long twig or stem per plant was taken for further fungal isolation.

Samples were first sterilized in $70 \%$ ethanol for $1 \mathrm{~min}$, immersed in a $5 \%$ sodium hypochlorite solution for $1 \mathrm{~min}$, and followed by rinsing two times in sterile distilled water ( $1 \mathrm{~min}$ per time). Fungal isolations were made by plating out pieces of plant tissues $(2-5 \mathrm{~mm})$ in potato dextrose agar plates (PDA, Merck, Germany). The plates were incubated at $25^{\circ} \mathrm{C}$ and checked daily for fungal growth. Each colony was transferred to fresh PDA plates, kept at $25{ }^{\circ} \mathrm{C}$ in the dark until typical Diaporthe colonies were observed, and monosporic cultures were then established, as previously described by Hilário et al. [8]. 
Table 1. List of plantations used for this study.

\begin{tabular}{|c|c|c|c|c|c|c|c|}
\hline \multirow{2}{*}{ Region } & \multirow{2}{*}{ Plantation } & \multicolumn{2}{|c|}{ GPS Coordinates } & \multirow{2}{*}{ Area (ha) } & \multirow{2}{*}{$\begin{array}{l}\text { Total of } \\
\text { Plants }\end{array}$} & \multirow{2}{*}{$\begin{array}{l}\text { Inspected } \\
\text { Plants }\end{array}$} & \multirow{2}{*}{$\begin{array}{c}\text { Sampled } \\
\text { Plants }\end{array}$} \\
\hline & & Latitude & Longitude & & & & \\
\hline \multirow{2}{*}{ Aveiro } & Águeda & $40^{\circ} 33^{\prime} 06.2^{\prime \prime} \mathrm{N}$ & $8^{\circ} 28^{\prime} 44.0^{\prime \prime} \mathrm{W}$ & 2.5 & 7000 & 35 & 10 \\
\hline & Arouca & $40^{\circ} 54^{\prime} 35.3^{\prime \prime} \mathrm{N}$ & $8^{\circ} 22^{\prime} 49.7^{\prime \prime} \mathrm{W}$ & 1.7 & 4400 & 22 & 9 \\
\hline \multirow{2}{*}{ Braga } & Urgezes & $41^{\circ} 25^{\prime} 24.5^{\prime \prime} \mathrm{N}$ & $8^{\circ} 17^{\prime} 35.1^{\prime \prime} \mathrm{W}$ & 2 & 4000 & 20 & 9 \\
\hline & $\begin{array}{l}\text { Póvoa de } \\
\text { Lanhoso }\end{array}$ & $41^{\circ} 31^{\prime} 35.0^{\prime \prime} \mathrm{N}$ & $8^{\circ} 15^{\prime} 08.3^{\prime \prime} \mathrm{W}$ & 1.5 & 4600 & 23 & 9 \\
\hline Castelo Branco & Idanha-a-Nova & $39^{\circ} 52^{\prime} 58.4^{\prime \prime} \mathrm{N}$ & $7^{\circ} 17^{\prime} 23.2^{\prime \prime} \mathrm{W}$ & 2.5 & 10,416 & 52 & 4 \\
\hline \multirow{4}{*}{ Porto } & Penafiel & $41^{\circ} 08^{\prime} 07.0^{\prime \prime} \mathrm{N}$ & $8^{\circ} 22^{\prime} 42.5^{\prime \prime} \mathrm{W}$ & 0.6 & 500 & 3 & 3 \\
\hline & Agrela & $41^{\circ} 08^{\prime} 07.0^{\prime \prime} \mathrm{N}$ & $8^{\circ} 28^{\prime} 09.7^{\prime \prime} \mathrm{W}$ & 1.8 & 6200 & 31 & 8 \\
\hline & Arcozelo & $41^{\circ} 15^{\prime} 31.8^{\prime \prime} \mathrm{N}$ & $8^{\circ} 28^{\prime} 57.8^{\prime \prime} \mathrm{W}$ & 2.3 & 8000 & 40 & 8 \\
\hline & Monte Córdova & $41^{\circ} 15^{\prime} 22.9^{\prime \prime} \mathrm{N}$ & $8^{\circ} 26^{\prime} 29.5^{\prime \prime} \mathrm{W}$ & 1 & 3084 & 15 & 9 \\
\hline \multirow{2}{*}{ Santarém } & Alpiarça & $39^{\circ} 15^{\prime} 04.1^{\prime \prime} \mathrm{N}$ & $8^{\circ} 32^{\prime} 39.1^{\prime \prime} \mathrm{W}$ & 6 & 20,000 & 100 & 8 \\
\hline & Ourém & $39^{\circ} 39^{\prime} 13.5^{\prime \prime} \mathrm{N}$ & $8^{\circ} 35^{\prime} 32.0^{\prime \prime} \mathrm{W}$ & 1.7 & 8000 & 40 & 9 \\
\hline Viseu & Mangualde & $40^{\circ} 37^{\prime} 43.2^{\prime \prime} \mathrm{N}$ & $7^{\circ} 51^{\prime} 51.8^{\prime \prime} \mathrm{W}$ & 7.4 & 31,091 & 150 & 9 \\
\hline
\end{tabular}

\subsection{Morphological Characterization}

To record the micromorphological characters of our isolates, sporulation was induced by plating 5 -mm-diameter mycelium plugs on medium supplemented with sterilized fennel stems and pine needles as described by Hilário et al. [8]. Conidiomata and ascomata were observed with a Nikon SMZ1500 stereomicroscope (Nikon, Japan) and photographed with a Digital Sight DS-Fi1 camera (Nikon, Japan). The fruiting bodies were cut in a drop of sterile water in a microscope slide, mounted in 100\% lactic acid and the micromorphological characters (e.g., conidia and ascospores size) were observed. All preparations were visualized with a Nikon 80i microscope (Nikon, Japan) with interference contrast equipment and captured with a Nikon Digital Sight DS-Ri1 camera (Nikon, Japan). About 50 conidia, or ascospores, were selected randomly and measured on images taken with the $\times 100$ objective lens. Dimensions of other fungal structures (e.g., conidiophores, asci) are given as the range of a minimum of 20 measurements. Data for spores, conidiophores and asci measurements are with the minimum and maximum dimensions in parentheses and followed by mean and standard deviation (S.D.). Colony colors were analyzed according to Syme [26] after 7 days of growth on PDA in the dark at $25^{\circ} \mathrm{C}$. Cultures were maintained in the personal collection of Artur Alves (CAA), University of Aveiro (Portugal).

\subsection{Molecular Characterization}

\subsubsection{DNA Extraction and PCR Amplification}

The genomic DNA of all fungal isolates was extracted from fresh mycelium and grown in PDA for seven days at $25^{\circ} \mathrm{C}$ according to a modified protocol by Möller [27]. Microsatellite-primed PCR (MSP-PCR) fingerprinting was performed using the (GTG) primer and following the description of Alves et al. [28]. Isolates were clustered based on their genetic profiles in a consensus dendrogram built with GelCompar II software (Applied Maths) using Pearson's correlation coefficient and the unweighted pair group method with arithmetic mean (UPGMA). A cut-off of approximately $82.5 \%$ was chosen as the reproducibility level, since strains from a cluster above this level are deemed to belong to the same species, as previously described by Santos and Phillips [29].

The rDNA internal transcribed spacer region (ITS), translation elongation factor 1alpha (tef1- $\alpha$ ), $\beta$-tubulin (tub2), calmodulin (cal) and histone 3 (his3) were the loci chosen to be sequenced in this study. Primers ITS5 and NL4 were used to amplify the ITS region [30] following a description by Alves et al. [31]. The remaining loci were amplified using the 
following primer sets: EF-688F/EF-1251R for tef1- $\alpha$ [32], T1/Bt2b for tub2 [33,34], CALD38F/CAL-737R for cal [8,35], and CYLH3F/H3-1bR for his3 [33,36]. PCR conditions were as described Hilário et al. [8]. The PCR reactions, with a final volume of $25 \mu \mathrm{L}$, were composed

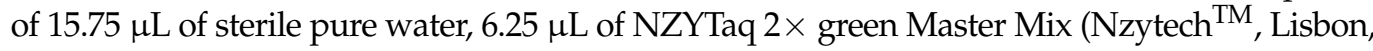
Portugal), $1 \mu \mathrm{L}$ of each primer at $10 \mathrm{pmol} / \mu \mathrm{L}$ and $1 \mu \mathrm{L}$ of DNA template and performed in a Bio-Rad C1000 touch thermal cycler (USA). PCR amplification products were checked using an electrophoresis in 1.5\% agarose gels and visualised under UV light (Gel DocTM XR+, BioRad, Hercules, CA, USA). Amplicons were purified using the NZYGelPure Kit (Nzytech ${ }^{\mathrm{TM}}$, Lisbon, Portugal) and sequenced by GATC Biotech (Cologne, Germany).

\subsubsection{Phylogenetic Analysis}

The nucleotide sequences were analyzed with FinchTV v.1.4.0 (Geospiza, Seattle, USA; www.geospiza.com/finchtv (accessed on 10 February 2021)). Sequences were aligned with ClustalX2.1 software [37] using pairwise alignment (gap opening $=10$, gap extension $=0.1$ ) and multiple alignment (gap opening $=10$, gap extension $=0.2$, transition weight $=0.5$, delay divergent sequences $=25 \%$ ). The alignments were optimized and edited manually using BioEdit Alignment Editor v.7.0.5. [38] and concatenated using Sequence Matrix [39].

Briefly, phylogenetic analyses were done using PAUP* v.4.0b10 [40] for Maximum Parsimony (MP) analyses, MrBayes v.3.0b4 [41] for Bayesian Inference (BI) analyses and MEGA v.7 [42] for Maximum Likelihood (ML) analyses [20]. Maximum Parsimony analyses were performed using PAUP* v. 4.0b10 [40]. For Maximum Parsimony, a branch-swapping algorithm, the heuristic search option with 100 random taxon additions, and the subtree pruning regrafting (SPR) method were applied. All characters were unordered and of equal weight, and gaps were treated as missing data. Maxtrees were set to 100 and branches of zero length were collapsed. Clade stability was assessed using a bootstrap analysis with 1000 replicates. Moreover, the following parameters were calculated: consistency index $(\mathrm{CI})$, retention index (RI), tree length (TL), rescaled consistency index (RC) and homoplasy index (HI).

Bayesian analyses were performed using a Markov Chain Monte Carlo sampling (MCMC). Four MCMC chains were run simultaneously, starting from random trees for $1,000,000$ generations and sampled every 100th generation for a total of 10,000 trees. The first 1000 were discarded as the burn-in phase of each analysis. Posterior probabilities (PP) were determined from a majority rule consensus tree generated with the remaining 9000 trees. The general time-reversible model of evolution assuming invariant sites and a gamma distribution was used for BI analyses [43].

Maximum likelihood analyses were carried out starting from a Neighbour-Joining tree automatically generated by the software. Nearest-Neighbour-Interchange (NNI) was used as the heuristic method for tree inference and 1000 bootstrap replicates were performed. MEGA v.7 was also used to determine the best nucleotide substitution model to build the ML trees. All trees were rooted to Diaporthela corylina and visualized with TreeView [44].

The identification of the clades containing our isolates was assessed through an initial ITS single tree containing all species currently accepted in the genus Diaporthe. Additionally, we also evaluated the possibility of combining all five loci (ITS, tef1- $\alpha$, tub2, cal, and his3). A comparison of highly supported clades among single locus trees (including solely the phylogenetically closely related species previously selected) was performed to check phylogenetic concordance among the individual gene trees (Figures S1-S6).

Trees were edited in Inkscape Vector software v.0.92 (https://www.inkscape.org, accessed on 25 May 2021) (Adobe Systems Inc, San Jose, CA, USA). Sequences generated in this study were deposited in GenBank (Table 2) (www.ncbi.nlm.nih.gov, accessed on 17 March 2021) and all phylogenetic trees and alignments (including the ITS single tree) were deposited in TreeBASE (www.TreeBASE.org (accessed on 4 December 2021)) under accession number S28393). 
Table 2. Diaporthe species used in this study.

\begin{tabular}{|c|c|c|c|c|c|c|c|c|}
\hline \multirow{2}{*}{ Species } & \multirow{2}{*}{ Strain ${ }^{1}$} & \multirow{2}{*}{ Host } & \multirow{2}{*}{ Locality } & \multicolumn{5}{|c|}{ GenBank Accession } \\
\hline & & & & ITS & tef1- $\alpha$ & $t u b 2$ & his3 & cal \\
\hline D. acaciigena & CBS 129521 & $\begin{array}{c}\text { Acacia } \\
\text { retinodes }\end{array}$ & Australia & КС343005 & КС343731 & КС343973 & КС343489 & КС343247 \\
\hline \multirow{4}{*}{ D. ambigua } & CBS 114015 & $\begin{array}{c}\text { Pyrus } \\
\text { communis }\end{array}$ & South Africa & КС343010 & КС343736 & КС343978 & КС343494 & KC343252 \\
\hline & CBS 123210 & $\begin{array}{l}\text { Foeniculum } \\
\text { vulgare }\end{array}$ & Portugal & КС343012 & КС343738 & КС343980 & КС343496 & КС 343254 \\
\hline & CBS 127746 & $\begin{array}{l}\text { Platanus } \\
\text { acerifolia }\end{array}$ & Italy & КС343014 & КС343740 & КС343982 & КС343498 & КС343256 \\
\hline & CAA957 & $\begin{array}{c}\text { Vaccinium } \\
\text { corymbosum }\end{array}$ & Portugal & MT073278 & MT051928 & MT051959 & MT051887 & MT051851 \\
\hline \multirow{8}{*}{ D. amygdali } & CBS 115620 & $\begin{array}{l}\text { Prunus } \\
\text { persica }\end{array}$ & USA & КС343020 & КС343746 & КС343988 & КС343504 & КС343262 \\
\hline & CBS 126679 & Prunus dulcis & Portugal & КС343022 & КС343748 & КС343990 & КС343506 & KC343264 \\
\hline & CBS 111811 & Vitis vinifera & South Africa & КС343019 & КС343745 & КС343987 & КС343503 & KC343261 \\
\hline & CAA958 & $\begin{array}{c}\text { Vaccinium } \\
\text { corymbosum }\end{array}$ & Portugal & MT073273 & MT051923 & MT051955 & MT051883 & MT051847 \\
\hline & CAA959 & $\begin{array}{l}\text { Vaccinium } \\
\text { corymbosum }\end{array}$ & Portugal & MT073283 & MT051935 & MT051970 & MT051898 & MT051862 \\
\hline & CFCC 52586 & $\begin{array}{c}\text { Kadsura } \\
\text { longipeduncu- } \\
\text { lata }\end{array}$ & China & MH121521 & MH121563 & MH121600 & MH121479 & MH121439 \\
\hline & CBS 136969 & $\begin{array}{l}\text { Vaccinium } \\
\text { corymbosum }\end{array}$ & Italy & KJ160579 & KJ160611 & KJ160528 & MF418350 & KJ160548 \\
\hline & CBS 146754 & Prunus dulcis & Spain & МT007489 & MT006989 & MT006686 & MT007095 & MT006761 \\
\hline D. anacardii & CBS 720.97 & $\begin{array}{c}\text { Anacardium } \\
\text { occidentale }\end{array}$ & East Africa & КС343024 & КС343750 & КС343992 & КС343508 & КС343266 \\
\hline D. angelicae & CBS 111592 & $\begin{array}{c}\text { Heracleum } \\
\text { sphondylium }\end{array}$ & Austria & КС343027 & КС343753 & КС343995 & КС343511 & КС343269 \\
\hline \multirow{2}{*}{$\begin{array}{c}\text { D. aus- } \\
\text { tralafricana }\end{array}$} & CBS 113486 & Vitis vinifera & South Africa & КС343038 & КС343764 & КС344006 & КС343522 & KC343280 \\
\hline & CBS 113487 & Vitis vinifera & South Africa & КС343039 & КС343765 & КС344007 & КС343523 & KC343281 \\
\hline \multirow{3}{*}{ D. baccae } & CBS 136972 & $\begin{array}{c}\text { Vaccinium } \\
\text { corymbosum }\end{array}$ & Italy & KJ160565 & KJ160597 & MF418509 & MF418264 & MG281695 \\
\hline & CBS 142546 & $\begin{array}{l}\text { Citrus } \\
\text { sinensis }\end{array}$ & Italy & MF418358 & MF418437 & MF418517 & MF418272 & MF418192 \\
\hline & CBS 142545 & $\begin{array}{l}\text { Citrus } \\
\text { sinensis }\end{array}$ & Italy & MF418351 & MF418430 & MF418510 & MF418265 & MF418185 \\
\hline D. beckhausii & CBS 138.27 & Viburnum sp. & - & КС343041 & КС343767 & КС344009 & КС343525 & КС343283 \\
\hline $\begin{array}{c}D . \\
\text { chamaeropis }\end{array}$ & CBS 454.81 & $\begin{array}{l}\text { Chamaerops } \\
\text { humilis }\end{array}$ & Greece & КС343048 & КС343774 & КС344016 & КС343532 & КС343290 \\
\hline D. cinerascens & CBS 719.96 & Ficus carica & Bulgaria & КС343050 & КС343776 & КС344018 & КС343534 & KC343292 \\
\hline \multirow{6}{*}{ D. crousii } & CAA821 & $\begin{array}{c}\text { Vaccinium } \\
\text { corymbosum }\end{array}$ & Portugal & MK792301 & MK828073 & MK837924 & MK871442 & MK883829 \\
\hline & MUM 19.29 & $\begin{array}{c}\text { Vaccinium } \\
\text { corymbosum }\end{array}$ & Portugal & MK792311 & MK828081 & MK837932 & MK871450 & MK883835 \\
\hline & CAA828 & $\begin{array}{l}\text { Vaccinium } \\
\text { corymbosum }\end{array}$ & Portugal & MK792317 & MK828084 & MK837935 & MK871453 & MK883837 \\
\hline & CAA960 & $\begin{array}{l}\text { Vaccinium } \\
\text { corymbosum }\end{array}$ & Portugal & MT073274 & MT051924 & MT051956 & MT051884 & MT051848 \\
\hline & CAA961 & $\begin{array}{l}\text { Vaccinium } \\
\text { corymbosum }\end{array}$ & Portugal & MT073275 & MT051925 & MT051957 & MT051885 & MT051849 \\
\hline & CAA962 & $\begin{array}{c}\text { Vaccinium } \\
\text { corymbosum }\end{array}$ & Portugal & МТ073301 & MT051926 & MT051962 & MT051890 & MT051854 \\
\hline
\end{tabular}


Table 2. Cont.

\begin{tabular}{|c|c|c|c|c|c|c|c|c|}
\hline \multirow{2}{*}{ Species } & \multirow{2}{*}{ Strain ${ }^{1}$} & \multirow{2}{*}{ Host } & \multirow{2}{*}{ Locality } & \multicolumn{5}{|c|}{ GenBank Accession } \\
\hline & & & & ITS & tef1- $\alpha$ & $t u b 2$ & his3 & cal \\
\hline D. cynaroidis & CBS 122676 & $\begin{array}{c}\text { Protea } \\
\text { cynaroides }\end{array}$ & South Africa & КС343058 & КС343784 & КС344026 & КС343542 & КС 343300 \\
\hline D. elaeagni & CBS 504.72 & Elaeagnus sp. & Netherlands & KC343064 & KC343790 & KC344032 & KC343548 & KC343306 \\
\hline \multirow{6}{*}{ D. foeniculina } & CBS 123208 & $\begin{array}{l}\text { Foeniculum } \\
\text { vulgare }\end{array}$ & Portugal & КС343104 & КС343830 & КС344072 & КС343588 & КС343346 \\
\hline & CBS 111553 & $\begin{array}{l}\text { Foeniculum } \\
\text { vulgare }\end{array}$ & Spain & КС343101 & КС343827 & КС344069 & КС343585 & КС343343 \\
\hline & СРС 28033 & $\begin{array}{l}\text { Citrus } \\
\text { sinensis }\end{array}$ & Portugal & MF418402 & MF418481 & MF418562 & MF418322 & MF418236 \\
\hline & CBS 187.27 & $\begin{array}{l}\text { Camelia } \\
\text { sinensis }\end{array}$ & Italy & КС343107 & КС343833 & КС344075 & КС343591 & КС343349 \\
\hline & CAA963 & $\begin{array}{c}\text { Vaccinium } \\
\text { corymbosum }\end{array}$ & Portugal & MT073311 & MT051932 & MT051965 & MT051893 & MT051857 \\
\hline & CAA967 & $\begin{array}{c}\text { Vaccinium } \\
\text { corymbosum }\end{array}$ & Portugal & MT073307 & MT051937 & MT051973 & MT051901 & MT051865 \\
\hline \multirow{3}{*}{ D. fusicola } & PSCG 030 & $\begin{array}{c}\text { Pyrus } \\
\text { pyrifolia }\end{array}$ & China & MK626914 & MK654864 & MK691323 & MK726255 & MK691211 \\
\hline & PSCG 118 & $\begin{array}{c}\text { Pyrus } \\
\text { pyrifolia }\end{array}$ & China & MK626910 & MK654860 & MK691317 & MK726250 & MK691204 \\
\hline & CBS 120840 & $\begin{array}{l}\text { Prunus } \\
\text { salicina }\end{array}$ & South Africa & КС343021 & КС343747 & КС343989 & КС343505 & КС 343263 \\
\hline D. infecunda & CBS 133812 & $\begin{array}{l}\text { Schinus tere- } \\
\text { binthifolius }\end{array}$ & Brazil & КС343126 & КС343852 & КС344094 & КС343610 & КС343368 \\
\hline \multirow[t]{2}{*}{ D. hybrida } & CAA998 & $\begin{array}{l}\text { Vaccinium } \\
\text { corymbosum }\end{array}$ & Portugal & MT073276 & MT051927 & MT051958 & MT051886 & MT051850 \\
\hline & $\begin{array}{c}\text { CAA999/MUM } \\
21.01\end{array}$ & $\begin{array}{c}\text { Vaccinium } \\
\text { corymbosum }\end{array}$ & Portugal & MT073280 & MT051929 & MT051960 & MT051888 & MT051852 \\
\hline \multirow[t]{2}{*}{$\begin{array}{c}\text { D. } \\
\text { leucospermi }\end{array}$} & CBS 111980 & $\begin{array}{l}\text { Leucospermum } \\
\text { sp. }\end{array}$ & Australia & JN712460 & KY435632 & KY435673 & KY435653 & KY435663 \\
\hline & CAA971 & $\begin{array}{c}\text { Vaccinium } \\
\text { corymbosum }\end{array}$ & Portugal & MT073313 & MT051933 & MT051968 & MT051896 & MT051860 \\
\hline D. longispora & CBS 194.36 & Ribes sp. & Canada & КС343135 & КС343861 & KC344103 & КС343619 & KC343377 \\
\hline \multirow{9}{*}{ D. malorum } & CBS 142383 & $\begin{array}{c}\text { Malus } \\
\text { domestica }\end{array}$ & Portugal & KY435638 & KY435627 & KY435668 & KY435648 & KY435658 \\
\hline & CAA740 & $\begin{array}{c}\text { Malus } \\
\text { domestica }\end{array}$ & Portugal & KY435642 & KY435629 & KY435670 & KY435650 & KY435660 \\
\hline & CAA752 & $\begin{array}{c}\text { Malus } \\
\text { domestica }\end{array}$ & Portugal & KY435643 & KY435630 & KY435671 & KY435651 & KY435661 \\
\hline & CAA972 & $\begin{array}{c}\text { Vaccinium } \\
\text { corymbosum }\end{array}$ & Portugal & МT073271 & MT051917 & MT051953 & MT051881 & MT051845 \\
\hline & CAA973 & $\begin{array}{l}\text { Vaccinium } \\
\text { corymbosum }\end{array}$ & Portugal & MT073272 & MT051918 & MT051954 & MT051882 & MT051846 \\
\hline & CAA974 & $\begin{array}{c}\text { Vaccinium } \\
\text { corymbosum }\end{array}$ & Portugal & MT073306 & MT051919 & MT051963 & MT051891 & MT051855 \\
\hline & CAA975 & $\begin{array}{c}\text { Vaccinium } \\
\text { corymbosum }\end{array}$ & Portugal & MT073304 & MT051920 & MT051966 & MT051894 & MT051858 \\
\hline & CAA976 & $\begin{array}{c}\text { Vaccinium } \\
\text { corymbosum }\end{array}$ & Portugal & MT073305 & MT051921 & MT051967 & MT051895 & MT051859 \\
\hline & CAA977 & $\begin{array}{l}\text { Vaccinium } \\
\text { corymbosum }\end{array}$ & Portugal & MT073303 & MT051922 & MT051971 & MT051899 & МT051863 \\
\hline D. parvae & PSCG 035 & $\begin{array}{c}\text { Pyrus } \times \\
\text { bretschneideri }\end{array}$ & China & MK626920 & MK654859 & MK691249 & MK726211 & MK691169 \\
\hline
\end{tabular}


Table 2. Cont.

\begin{tabular}{|c|c|c|c|c|c|c|c|c|}
\hline \multirow{2}{*}{ Species } & \multirow{2}{*}{ Strain ${ }^{1}$} & \multirow{2}{*}{ Host } & \multirow{2}{*}{ Locality } & \multicolumn{5}{|c|}{ GenBank Accession } \\
\hline & & & & ITS & $t e f 1-\alpha$ & $t u b 2$ & his3 & cal \\
\hline D. passiflorae & CBS 132527 & $\begin{array}{c}\text { Passiflora } \\
\text { edulis }\end{array}$ & $\begin{array}{c}\text { South } \\
\text { America }\end{array}$ & JX069860 & KY435633 & KY435674 & KY435654 & KY435664 \\
\hline \multirow[t]{2}{*}{ D. phillipsii } & MUM 19.28 & $\begin{array}{c}\text { Vaccinium } \\
\text { corymbosum }\end{array}$ & Portugal & MK792305 & MK828076 & MN000351 & MK871445 & MK883831 \\
\hline & CAA818 & $\begin{array}{l}\text { Vaccinium } \\
\text { corymbosum }\end{array}$ & Portugal & MK792307 & MK828078 & MN000352 & MK871447 & MK883833 \\
\hline \multirow{2}{*}{$\begin{array}{c}D . \\
\text { portugallica }\end{array}$} & CBS 144228 & $\begin{array}{l}\text { Camelia } \\
\text { sinensis }\end{array}$ & Portugal & MH063905 & MH063911 & MH063917 & MH063899 & MH063893 \\
\hline & СРС 34248 & $\begin{array}{l}\text { Camelia } \\
\text { sinensis }\end{array}$ & Portugal & MH063906 & MH063912 & MH063918 & MH063900 & MH063894 \\
\hline \multirow{2}{*}{$\begin{array}{c}\text { D. } \\
\text { pyracanthae }\end{array}$} & CAA487 & $\begin{array}{c}\text { Pyracantha } \\
\text { coccinea }\end{array}$ & Portugal & KY435636 & KY435626 & KY435667 & KY435647 & KY435657 \\
\hline & CBS142384 & $\begin{array}{c}\text { Pyracantha } \\
\text { coccinea }\end{array}$ & Portugal & KY435635 & KY435625 & KY435666 & KY435646 & KY435656 \\
\hline \multirow[t]{2}{*}{ D. rossmaniae } & CAA763 & $\begin{array}{l}\text { Vaccinium } \\
\text { corymbosum }\end{array}$ & Portugal & MK792291 & MK828064 & MK837915 & MK871433 & MK883823 \\
\hline & MUM 19.30 & $\begin{array}{l}\text { Vaccinium } \\
\text { corymbosum }\end{array}$ & Portugal & MK792290 & MK828063 & MK837914 & MK871432 & MK883822 \\
\hline \multirow{6}{*}{ D. rudis } & CBS 114436 & $\begin{array}{l}\text { Laburnum } \\
\text { anagyroides }\end{array}$ & Austria & КС343232 & КС343958 & КС344200 & КС343716 & КС343474 \\
\hline & CBS 113201 & Vitis vinifera & Portugal & КС343234 & КС343960 & КС344202 & КС343718 & КC343476 \\
\hline & CAA979 & $\begin{array}{l}\text { Vaccinium } \\
\text { corymbosum }\end{array}$ & Portugal & MT073290 & MT051930 & MT051961 & MT051889 & MT051853 \\
\hline & CAA984 & $\begin{array}{l}\text { Vaccinium } \\
\text { corymbosum }\end{array}$ & Portugal & МT073282 & MT051931 & MT051964 & MT051892 & MT051856 \\
\hline & CAA987 & $\begin{array}{l}\text { Vaccinium } \\
\text { corymbosum }\end{array}$ & Portugal & MT073314 & MT051934 & MT051969 & MT051897 & MT051861 \\
\hline & CAA991 & $\begin{array}{l}\text { Vaccinium } \\
\text { corymbosum }\end{array}$ & Portugal & МТ073291 & MT051936 & MT051972 & MT051900 & MT051864 \\
\hline $\begin{array}{c}D . \\
\text { sclerotioides }\end{array}$ & CBS 296.67 & $\begin{array}{l}\text { Cucumis } \\
\text { sativus }\end{array}$ & Netherlands & КС343193 & КС343919 & КС344161 & КС343677 & КС343435 \\
\hline D. sterilis & CBS 136969 & $\begin{array}{l}\text { Vaccinium } \\
\text { corymbosum }\end{array}$ & Italy & KJ160579 & KJ160611 & KJ160528 & MF418350 & KJ160548 \\
\hline D. stictica & CBS 370.54 & $\begin{array}{c}\text { Buxus } \\
\text { sempervirens }\end{array}$ & Italy & КС343212 & КС343938 & КС344180 & КС343696 & КС343454 \\
\hline $\begin{array}{c}\text { Diaporthella } \\
\text { corylina }\end{array}$ & CBS 121124 & Corylus sp. & China & КС343004 & КС343730 & КС343972 & КС343488 & KC343246 \\
\hline
\end{tabular}

${ }^{1}$ Acronyms of culture collection: CAA-Personal Culture Collection Artur Alves, University of Aveiro, Aveiro, Portugal; CBS-Westerdijk Fungal Biodiversity Institute, Utrecht, The Netherlands; CFCC—China Forestry Culture Collection Center, Beijing, China; CPC—Personal culture Collection Pedro W. Crous, hosted at CBS; MUM-Culture Collection from Micoteca at Universidade of Minho, Center for Biological Engineering, Braga, Portugal. PSCG-Personal Culture Collection Y.S. Guo, China. Ex-type isolates are in bold face. Newly sequences generated in this study are in italics.

\subsection{Mating-Type Assay}

The mating type of the new species was determined by a PCR-based method. Primers MAT1-1-1FW and MAT1-1-1-RV at $40 \mathrm{pmol} / \mu \mathrm{L}$ were used to amplify part of the MAT1-1-1 gene and the primers set MAT2 188F [8] and MAT1-2-1RV [15] at $10 \mathrm{pmol} / \mu \mathrm{L}$ used to amplify part of the MAT1-2-1 gene. PCR conditions were as described by Hilário et al. [8].

\subsection{Prevalence of Diaporthe Species}

The prevalence of Diaporthe species in the Vaccinium corymbosum plants sampled was calculated as previously described by Fu et al. [45]. The Isolation Rate (RI) was calculated 
for each species using Equation (1), where NS was the number of isolates from the same species, and NI was the total number of isolates collected during the survey.

$$
\mathrm{RI} \%=\left(\frac{\mathrm{NS}}{\mathrm{NI}}\right) \times 100
$$

\subsection{Plant Material and Pathogenicity Tests}

A minimum of three isolates from each species identified and from different locations, whenever possible, were selected to inoculate blueberry plants. Moreover, several other fungal isolates obtained from V. corymbosum plants sampled in a previous work (Table 3) [8] and the ex-type strain of Diaporthe vaccinii (CBS 160.32) were also selected to perform the pathogenicity tests. This latter strain was obtained from the Westerdijk Fungal Biodiversity Institute in the Netherlands.

Table 3. Fungal isolates used and obtained from a previous study (Hilário et al. [8]).

\begin{tabular}{cc}
\hline Species & Isolate \\
\hline Diaporthe crousii & CAA823 \\
\hline Diaporthe eres & CAA829 \\
\hline Diaporthe leucospermi & CAA830 \\
\hline Diaporthe phillipsii & CAA762 \\
\hline & CAA817 \\
\hline
\end{tabular}

The pathogenicity trials were performed from 9 June 2020 until 14 July 2020. Three cultivars of blueberry plants currently used in Portuguese plantations were selected: 'Duke'the most cultivated in the northern area; 'Legacy' - the best suited to the climate in the southern area [46]; and 'Spartan'-alleged to be highly susceptible to infection by Diaporthe vaccinii [47]. Nine-month-old potted plants were obtained through the micropropagation method, thus assuring genetic homogeneity. All plants were supplied by Deifil Green Biotechnology LDA (Portugal). After arrival, plants were subjected to a 15-day acclimation period. Both acclimation period and the pathogenicity trials occurred in greenhouse conditions, with daily temperature ranging from $25^{\circ} \mathrm{C}$ during the day to $15^{\circ} \mathrm{C}$ at night, with a controlled photoperiod of $16 / 8 \mathrm{~h}$ (day/night) and watered regularly.

For inoculation, a wound was made on the stem $5 \mathrm{~cm}$ above the soil surface using a sterile scalpel, removing the bark, and exposing the cambium. A 5-mm-diameter mycelial plug was taken from 7-day-old cultures on PDA and placed in the wounded area with the mycelium in contact with the cambium. The inoculation site was sealed with Parafilm ${ }^{\circledR}$ to avoid dehydration. Plugs of sterile PDA were used to inoculate stems of control plants. External symptoms such as stem necrosis, wilting and dieback were assessed weekly and registered. Thirty-five days after inoculation, the bark was removed to measure the length of the internal lesions. Fungi were re-isolated on PDA to confirm Koch's postulates. Pieces of wood from the edges of lesions were immersed in 70\% ethanol for $1 \mathrm{~min}$, transferred to $5 \%$ sodium hypochlorite solution for $1 \mathrm{~min}$, and then rinsed twice in sterile distilled water. These wood tissues were plated on PDA, incubated at room temperature, and checked daily for fungal growth.

The analyses were performed considering individual isolates and species. One-way analysis of variance (ANOVA) assumptions were verified using a Shapiro-Wilk test. The homogeneity of variances was also checked using the Bartletts's test. As the datasets did not meet ANOVA assumptions, the analysis was performed using the Kruskal-Wallis test. Lesion length means of the different isolates were compared with one another using the Dunn Test with $p<0.05$. The different species were compared with one another, using the Wilcoxon rank sum test (with $p<0.05$ ). Statistical analyses as well as box plots were 
generated and conducted in R Statistical Software v. 4.0.1 [48], along with the GGPLOT2 package [49].

\section{Results}

\subsection{Fungal Isolation}

Twelve plantations, harboring nearly 65,280 plants and corresponding to 31 ha, were evaluated in several blueberry growing regions in Portugal (Figure 1). From these plants, 95 plants from the cultivars 'Duke' $(n=60)$, 'Ozarkblue' $(n=2)$, 'Aurora' $(n=7)$, 'O'Neal' $(n=1)$, 'Gupton' $(n=6)$, 'Legacy' $(n=11)$, 'Bluecrop' $(n=10)$, 'Liberty' $(n=2)$ and 'New Hanover' $(n=1)$ were collected. Symptoms such as dieback and necrosis of twigs and stems were observed in all sampled plants. The infections advanced towards the apex, developing necrosis above young shoots (Figure 2A). These symptoms were also accompanied by cankers that initially appeared as reddish to brown lesions on green twigs (Figure 2B) and later on the aged stems at the base (Figure 2C). Twig blight symptoms were also visible, developing red to rust lesion-like areas on the newer shoots, and reddish spots around buds (Figure 2D). Foliage on these diseased plants tended to redden or turn yellow, followed by leaf necrosis (Figure 2E). Additionally, in some plants, dieback led to necrosis of the vascular tissues and consequently to the twigs' death (Figure 2F). From the symptomatic blueberry samples, we obtained a collection of 116 isolates with characteristic diaporthalean colonies (white to dirty white felty mycelium spreading in a radial pattern and reverse with concentric zones) and micromorphological characteristics typical of the genus Diaporthe (alpha and beta conidia).

This genus was isolated from all regions surveyed although with different abundance values: Urgezes (21.6\%), Arcozelo (15.5\%), Ourém (11.2\%), Águeda and Póvoa de Lanhoso $(10.3 \%)$, Agrela (9.5\%), Mangualde (6.9\%), Arouca (6\%), Monte Córdova (4.3\%), Penafiel $(2.6 \%)$, Alpiarça and Idanha-a-Nova (0.9\%). 


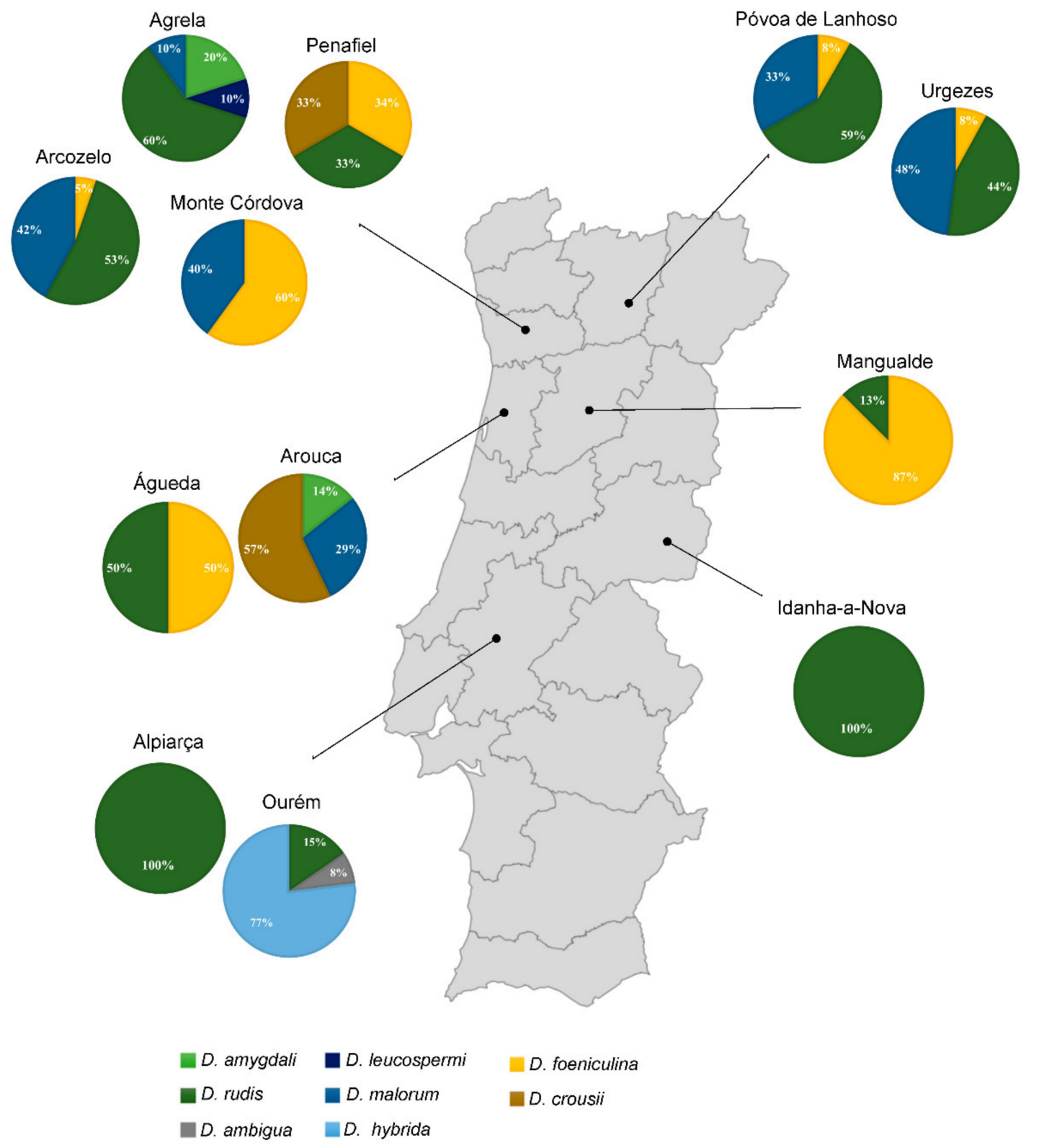

Figure 1. Frequency of Diaporthe species and distribution according to their sampling location.
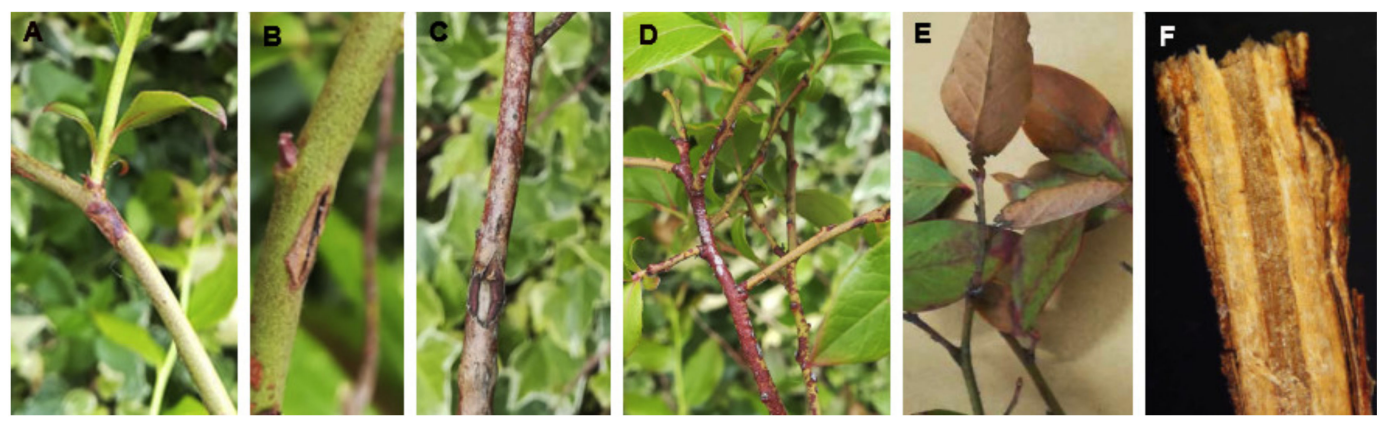

Figure 2. Symptoms on Vaccinium corymbosum associated with Diaporthe species. (A)-Necrosis evolving right below a young shoot; (B)—Canker on a green twig. (C) — Canker on older stems developing at the base. (D) — Twig bight with visible red to rust areas. (E) — Leaf discoloration. (F) - Vascular system of a dead twig. 


\subsection{Molecular Characterization}

MSP-PCR fingerprinting was performed to assess the genetic diversity of the 116 fungal isolates. A total of 21 isolates representative of each cluster, and from different geographic regions and cultivars whenever possible, were selected for further molecular characterization (Table 4).

Table 4. Diaporthe isolates collected from Vaccinium corymbosum plants, used in the phylogenetic analysis.

\begin{tabular}{|c|c|c|c|c|c|c|}
\hline \multirow{2}{*}{ Species } & \multirow{2}{*}{ Strain ${ }^{1}$} & \multirow{2}{*}{ Cultivar } & \multirow{2}{*}{ Symptoms } & \multirow{2}{*}{ Location } & \multicolumn{2}{|c|}{ Mating-Type } \\
\hline & & & & & MAT1-1-1 & MAT1-2-1 \\
\hline D. ambigua & CAA957 & Duke & Dead stem & Ourém & $(+)$ & $(+)$ \\
\hline \multirow{2}{*}{ D. amygdali } & CAA958 & Aurora & Twig blight & Arouca & $(+)$ & $(-)$ \\
\hline & CAA959 & Duke & Twig blight & Agrela & $(+)$ & $(-)$ \\
\hline \multirow{3}{*}{ D. crousii } & CAA960 & Aurora & Twig blight & Arouca & $(+)$ & $(+)$ \\
\hline & CAA961 & Aurora & Twig blight & Arouca & $(+)$ & $(+)$ \\
\hline & CAA962 & Legacy & Dead stem & Penafiel & $(+)$ & $(+)$ \\
\hline \multirow{2}{*}{ D. foeniculina } & CAA963 & Duke & Dead twig & Urgezes & $(-)$ & $(+)$ \\
\hline & CAA967 & Aurora & Dieback & Mangualde & $(-)$ & $(+)$ \\
\hline \multirow{2}{*}{ D. hybrida } & CAA998 & Duke & Twig blight & Ourém & $(+)$ & $(-)$ \\
\hline & CAA999 & Duke & Twig blight & Ourém & $(+)$ & $(-)$ \\
\hline D. leucospermi & CAA971 & Duke & Dead twig & Agrela & $(+)$ & $(-)$ \\
\hline \multirow{6}{*}{ D. malorum } & CAA972 & Aurora & Twig blight & Arouca & $(-)$ & $(+)$ \\
\hline & CAA973 & Aurora & Twig blight & Arouca & $(-)$ & $(+)$ \\
\hline & CAA974 & Duke & Dieback & Póvoa de Lanhoso & $(+)$ & $(-)$ \\
\hline & CAA975 & Duke & Dead twig & Urgezes & $(+)$ & $(-)$ \\
\hline & CAA976 & Duke & Dead twig & Urgezes & $(+)$ & $(-)$ \\
\hline & CAA977 & Duke & Dieback & Arcozelo & $(+)$ & $(-)$ \\
\hline \multirow{4}{*}{ D. rudis } & CAA979 & O'Neal & Stem blight & Ourém & $(+)$ & $(+)$ \\
\hline & CAA984 & Duke & Dead twig & Urgezes & $(+)$ & $(+)$ \\
\hline & CAA987 & Duke & Twig blight & Agrela & $(+)$ & $(+)$ \\
\hline & CAA991 & Duke & Twig blight & Arcozelo & $(+)$ & $(+)$ \\
\hline
\end{tabular}

${ }^{1}$ Acronym of collection: CAA-Culture Collection of Artur Alves, University of Aveiro, Portugal.

A primary identification using the ITS sequences of our isolates was done using BLASTn. The analysis revealed that our sequences matched to members of Diaporthe with high values of identity ( $98 \%$ to $100 \%)$, thus confirming the identity of our isolates. Afterwards, a multilocus analysis using ITS, tef1- $\alpha, t u b 2$, cal and his3 loci was performed, which included those species phylogenetically closely related to our isolates and whose 5 loci are available (Table 2).

The 5-loci concatenated alignment contained 2652 characters including gaps (599 from ITS, 458 from tef1-a, 513 from tub2, 546 from cal and 536 from his3). Of these 2652 characters, 1429 were constant, 344 were variable and parsimony uninformative and 879 were parsimony informative. MP analysis resulted in 100 equal, most parsimonious trees with $\mathrm{TL}=3263$ steps, $\mathrm{CI}=0.5786, \mathrm{RI}=0.9049, \mathrm{RC}=0.5236$ and $\mathrm{HI}=0.4789$. The analysis included 1 outgroup (Diaporthella corylina CBS 121124) and 76 taxa (22 sequences obtained in this study and 54 Diaporthe sequences retrieved from GenBank). The isolates from this study grouped in eight clades (Figure 3). 


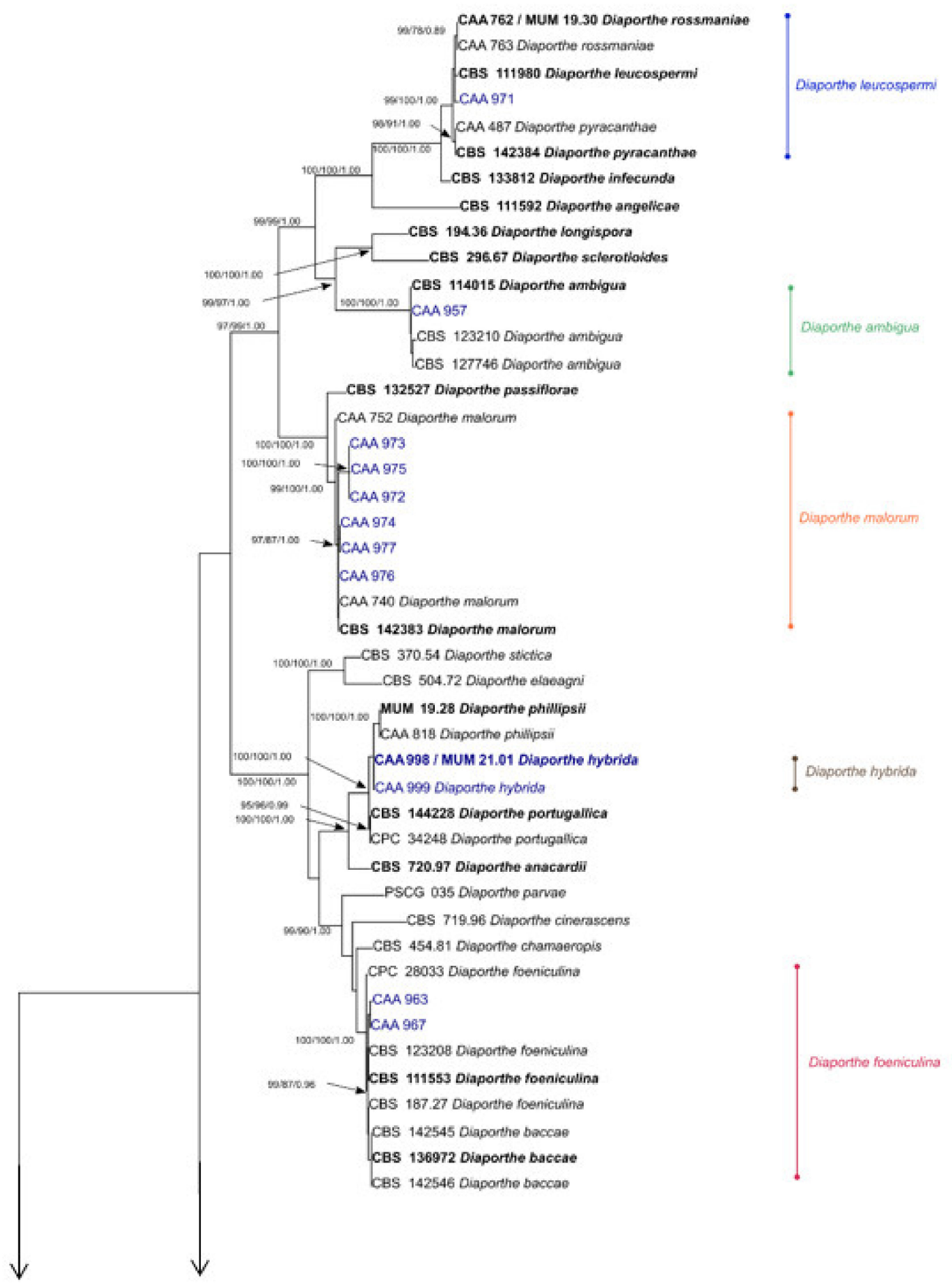

Figure 3. Cont. 


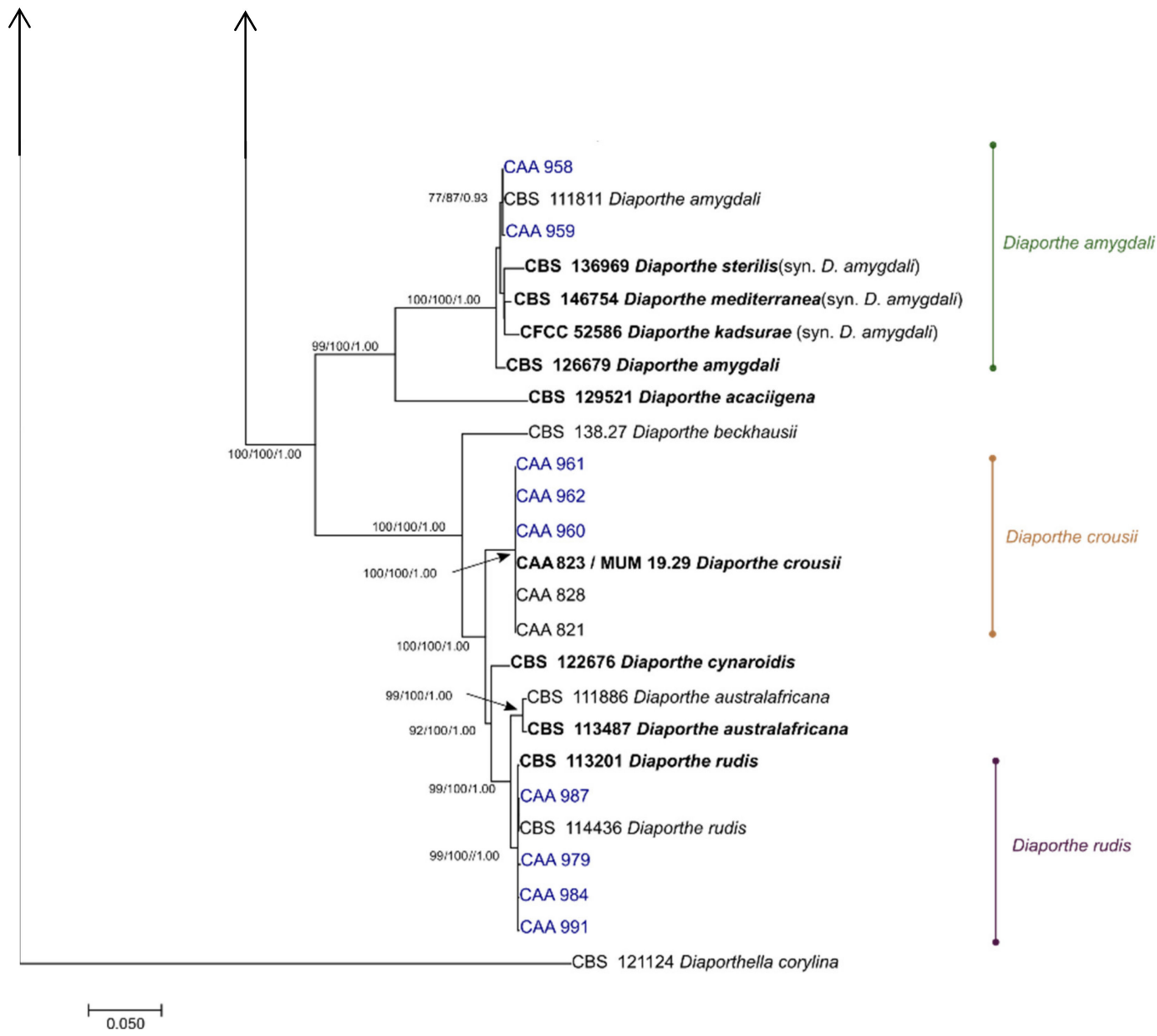

Figure 3. Phylogenetic relationships generated from maximum likelihood analysis based on ITS, tef1- $\alpha$, tub2, cal and his3 sequence data from Diaporthe species. The ML tree is drawn to scale with branch lengths measured in the number of substitutions per site and rooted to Diaporthella corylina. Maximum likelihood and maximum parsimony bootstrap values greater than $70 \%$ and posterior probabilities (PPs) inferred by Bayesian analysis greater than 0.80 are shown at the nodes. The ex-type strains are in bold.

Four isolates clustered within the well-supported Diaporthe rudis clade $(\mathrm{ML} / \mathrm{MP} / \mathrm{PP}=$ 99/100/1.00); three isolates clustered with D. crousii (ML/MP/PP = 100/100/1.00); only one isolate grouped with D. ambigua $(\mathrm{ML} / \mathrm{MP} / \mathrm{PP}=100 / 100 / 1.00)$; two isolates fitted in a monophyletic clade containing the species D. amygdali (ML/MP/PP = 100/100/1.00); six isolates are deemed to belong to D. malorum (ML/MP/PP =99/100/1.00); and two other isolates (D. hybrida) clustered between $D$. portugallica and D. phillipsii.

Isolate CAA971 clustered together with the ex-type strains of D. rossmaniae, D. leucospermi and D. pyracanthae forming a highly supported monophyletic clade (ML/MP/PP $=99 / 100 / 1.00)$. A pairwise alignment showed that CAA971 shares polymorphisms either with $D$. pyracanthae or D. rossmaniae in his3; with D. leucospermi in ITS, with D. pyracanthae in tef1- $\alpha$; and with $D$. rossmaniae in tub2. Only in the cal locus, CAA971 differs from the remaining three species in the presence of three unique polymorphisms.

Isolates CAA963 and CAA967 fell within a highly supported clade (ML/MP/PP $=100 / 100 / 1.00$ ) containing the type species of $D$. foeniculina and $D$. baccae. A pairwise comparison revealed that our isolates are $100 \%$ identical to $D$. foeniculina and $D$. baccae in tef1- $\alpha$ and tub2 loci, and 100\% identical to D. foeniculina in ITS locus. Moreover, in cal locus, only three unique polymorphisms separate our isolates from these species, while in his3 locus, it was observed polymorphisms were either $D$. baccae or D. foeniculina. 


\subsection{Distribution and Prevalence of Diaporthe Species}

Table 5 summarizes the number of isolates collected from diseased plants and the prevalence of each species found in this study. Overall, Diaporthe species were found in all 95 plants collected showing twig blight and dieback symptoms. From the total 116 diaporthalean isolates, Diaporthe rudis was the dominant species representing $38.8 \%$ of the isolates obtained, followed by D. malorum and D. foeniculina with an abundance of $25 \%$ and $19 \%$, respectively. At least two different species were found in ten of the twelve blueberry orchards. Diaporthe rudis, D. foeniculina and D. malorum were found in six surveyed plantations. Diaporthe ambigua, D. leucospermi and D. hybrida were recovered from one orchard only, each one in different regions.

Some of the species collected were found co-existing with other species in the same plant, while others were isolated without the co-occurrence of other members of Diaporthe. For instance, D. rudis was found in association with D. malorum, D. foeniculina, D. leucospermi, $D$. crousii and $D$. hybrida. Diaporthe amygdali was also found co-existing with $D$. crousii; $D$. leucospermi was recovered from the same plant material along with $D$. malorum, while $D$. ambigua was only recovered without the co-occurrence of other species (Table S1).

Table 5. Number of isolates and prevalence of each Diaporthe species obtained from blueberry orchards.

\begin{tabular}{ccc}
\hline Species & Number of Isolates & Prevalence (\%) \\
\hline D. ambigua & 1 & $0.9 \%$ \\
\hline D. amygdali & 3 & $2.5 \%$ \\
\hline D. crousii & 5 & $4.3 \%$ \\
\hline D. foeniculina & 22 & $19.0 \%$ \\
\hline D. leucospermi & 1 & $0.9 \%$ \\
\hline D. malorum & 29 & $25.0 \%$ \\
\hline D. rudis & 45 & $38.8 \%$ \\
\hline Diaporthe hybrida & 10 & $8.6 \%$ \\
\hline TOTAL & 116 & $100 \%$ \\
\hline
\end{tabular}

\subsection{Pathogenicity Tests}

\subsubsection{Plant Mortality}

Mortality (100\%) occurred only for the cultivar 'Duke' inoculated with D. eres (CAA829) (isolated from a previous work, Table 3) at different days post inoculation (Figure S7). Additionally, 20\% mortality was observed for cultivar 'Duke' inoculated with D. eres (CAA830), D. amygdali (CAA958, CAA959), D. malorum (CAA975), D. crousii (CAA962) and D. hybrida (CAA998). Moreover, 25\% mortality was observed also in 'Duke', after inoculation with D. hybrida (CAA998). The cultivar 'Legacy' showed 20\% mortality after inoculations with D. hybrida (CAA998) and D. amygdali (CAA958) (Figure S8). Isolates CAA962 (D. crousii), CAA958 (D. amygdali) and CAA830 (D. eres) were the only ones to cause $20 \%$ mortality in the cultivar 'Spartan' (Figure S9). Besides mortality, all these plants showed symptoms such as wilting and dead leaves, dieback, extensive discoloration of the outer epidermis, necrosis of the vascular tissues, twig blight and dead twigs (Figure 4). The remaining plants that survived did not exhibit any of these symptoms, apart from the development of necrotic lesions around the inoculation point at the end of the experiment. 

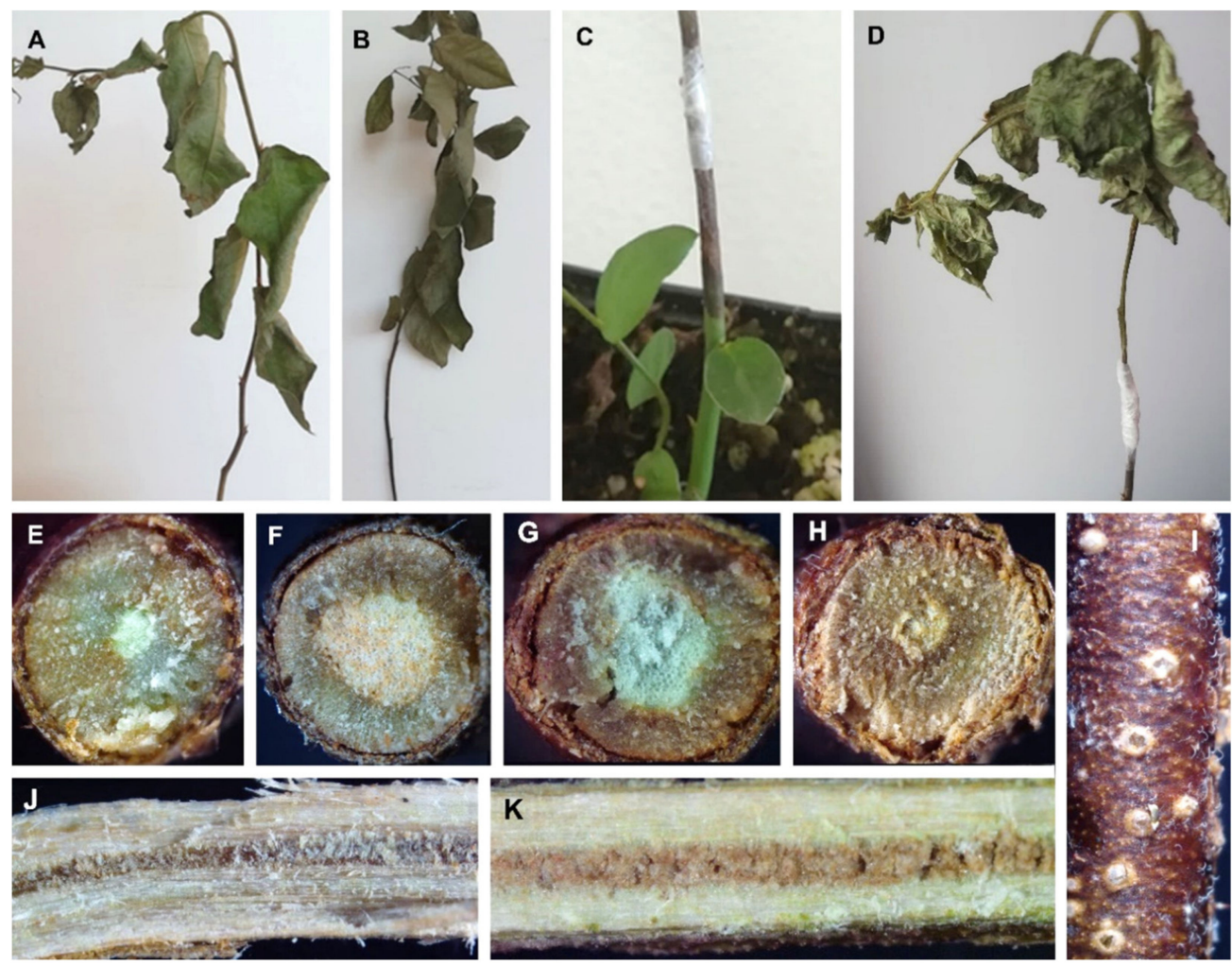

Figure 4. Representative symptoms of twig dieback and lesions induced by inoculation of wounded blueberry plants (cv. 'Duke', 'Spartan' and 'Legacy'). (A)—Death plant (cv. 'Duke') induced by CAA829. (B) - Death plant (cv. 'Legacy') induced by CAA958. (C)—Stem lesion developing from the inoculation site (cv. 'Spartan') caused by CAA958. (D)—Death plant (cv. 'Duke') induced by CAA999. (E-H)—Cross section of blueberry twigs showing discoloration of the vascular tissues well into the xylem, after infection by CAA830 (cv. ‘Duke'), CAA975 (cv. 'Duke'), CAA998 (cv. 'Legacy'), CAA958 (cv. ‘Duke') respectively. (I) - Pycnidia development of CAA975 on an inoculated twig. (J,K)-Necrotic internal tissues of twigs inoculated with CAA829 (cv. 'Duke') and CAA998 (cv. 'Legacy').

\subsubsection{Lesion Length Measurements}

Lesion lengths were measured 35 days after the inoculation. The outer bark was carefully removed, and the internal lesions which correspond to the necrotic woody tissues were measured. A Shapiro-Wilk test for normality showed that the data differed significantly from a normal distribution for all three cultivars tested $(\mathrm{W}=0.76, p<0.05$ for 'Duke'; $\mathrm{W}=0.65, p<0.05$ for 'Legacy'; $\mathrm{W}=0.78, p<0.05$ for 'Spartan'). Moreover, the homogeneity of variances, another assumption of linear tests (Bartlett's test) did not meet a normal distribution with $p<0.05$ for all cultivars. Thus, the Kruskal-Wallis test was applied, indicating that there are statistical differences among isolates from all three cultivars tested, with $p<0.05$. A Dunn's Test was used to compare all isolates, while the different species were compared with one another, using the Wilcoxon rank test.

All Diaporthe isolates inoculated on nine-month-year old plants of blueberry cultivars 'Duke', 'Legacy' and 'Spartan', caused necrotic lesions. Differences in aggressiveness were observed among isolates from the same species (Figure 5), and the differences varied according to the cultivar inoculated. For instance, in the cultivar 'Duke', isolate CAA975 (D. malorum $)$ caused significantly larger lesions $(5.9 \pm 2.7 \mathrm{~cm})$ than isolate CAA972 $(2.4 \pm 0.6 \mathrm{~cm}$, $p=0.0241)$. Moreover, in the cultivar 'Legacy', a homogeneity in the lesion lengths was observed. Nevertheless, a statistically significant difference in the lesion length was observed between isolates of D. foeniculina: CAA967 $(2.0 \pm 0.5 \mathrm{~cm})$ and CAA963 $(1.2 \pm 0.4 \mathrm{~cm}$, $p=0.0273)$. Moreover, in the cultivar 'Spartan', a statistically significant lesion size was also observed between CAA967 (D. foeniculina) $(2.4 \pm 0.3 \mathrm{~cm})$ and CAA963 (D. foeniculina) 
$(1.4 \pm 0.5 \mathrm{~cm}, p=0.0181)$. It is interesting to note, for instance, that lesions in cultivar 'Spartan', caused by isolate CAA998 (D. hybrida) $(3.0 \pm 1.5 \mathrm{~cm})$ are significantly larger than those caused by its parental species D. phillipsii (CAA818) $(1.5 \pm 0.3 \mathrm{~cm}, p=0.0149)$. A similar trend was verified in the cultivar 'Duke': the isolate CAA998 $(5.0 \pm 3.0 \mathrm{~cm})$ caused lesions significantly larger than those caused by its parental isolates CAA818 $(1.9 \pm 0.6 \mathrm{~cm}$, $p=0.0087)$ and CAA817 $(1.8 \pm 0.4 \mathrm{~cm}, p=0.0049)$.

When analysing the different Diaporthe species, differences in mean lesion length were observed (Figure S6). For instance, D. eres (isolates CAA829 and CAA830) was the most aggressive species in cultivar 'Duke', which caused the death of all replicates and with significantly larger internal necrotic lesions than any of the other species tested $(5.9 \pm 1.4 \mathrm{~cm})$, except those of $D$. hybrida $(3.5 \pm 1.6 \mathrm{~cm}, p=0.0554)$. Moreover, there were no statistical differences in the cultivars 'Legacy' and 'Spartan' among lesions caused by strains CBS 160.32, CAA829 and CAA830 (D. eres). In general, the cultivar 'Duke' showed larger internal lesions than 'Spartan' and 'Legacy'. The cultivar 'Duke' also presented a great variability between isolates (Figure 5). Overall, the species D. eres and D. amygdali induced the longest lesion lengths in all cultivars tested. Contrarily, the smallest lesion size was observed in D. foeniculina and D. leucospermi (Figure S6). At the end of the experiment, no lesions were seen in control plants. All the fungal species inoculated were re-isolated, thus verifying Koch's postulates.

\subsection{Taxonomy}

In this section, descriptions and illustrations of the species isolated from Vaccinium corymbosum plants are provided. Additionally, synonymous names for a few Diaporthe species are proposed, which are followed by a brief note based on phylogenetic analyses and morphological characters.

Diaporthe ambigua Nitschke, Pyrenomycetes Germanici: 311 (1867). Mycobank 193681 (Figure 6).

Specimen examined: Portugal, Santarém, Ourém, from dead stems of Vaccinium corymbosum, July 2019, S. Hilário, living culture: CAA957.

Sexual morph: Perithecial ascomata globose, aggregated, emerging through fennel stems. Perithecial necks black, subcylindrical, tapering towards the apex. Asci unitunicate, cylindrical to clavate, 8-spored, (48.7-)49.5-53.6(-54.7) $\times(6.9-) 7.1-8.1(-8.2) \mu \mathrm{m}$, (mean \pm S.D. $=51.5 \pm 2.4 \times 7.6 \pm 0.6 \mu \mathrm{m}, \mathrm{n}=10)$. Ascospores hyaline, smooth, fusoid-ellipsoidal, septate, tapering towards both ends, frequently tetraguttulate, $(9.5-) 10.9-11.5(-12.8) \times$ $(2.9-) 3.3-3.5(-3.9) \mu \mathrm{m},($ mean \pm S.D. $=11.2 \pm 0.9 \times 3.4 \pm 0.2 \mu \mathrm{m}, \mathrm{n}=50)$. Asexual morph: Conidiomata brown, erumpent from fennel stems, extruding white conidial mass. Conidiophores subcylindrical, septate at the base, frequently unbranched, (11.8-)16.2-21.4(-24.4) $\times(1.2-) 1.4-1.8(-2.3) \mu \mathrm{m},($ mean \pm S.D. $=18.8 \pm 4.2 \times 1.6 \pm 0.3 \mu \mathrm{m}, \mathrm{n}=30)$. Paraphyses not observed. Alpha conidia ellipsoidal, biguttulate, with an obtuse apex and rounded at the other end, $(4.6-) 6.0-6.3(-7.3) \times(1.9-) 2.4-2.6(-3.1) \mu \mathrm{m}$, (mean \pm S.D. $=6.1 \pm 0.6 \times$ $2.5 \pm 0.3 \mu \mathrm{m}, \mathrm{n}=100)$. Beta and gamma conidia not observed.

Sexual strategy: homothallism.

Culture characteristics: on PDA at $25^{\circ} \mathrm{C}$ after 7 days, mycelium flat, spreading with sparse, white to dirty white dense aerial mycelium and with solid patches of olivaceous black; reverse with brownish orange patches in the central part, surrounded by orpiment to buff orange cream areas.

Host range: Aspalathus linearis, Malus domestica, Malus sylvestris, Prunus salicina, Prunus sp., Pyrus communis, Vitis vinifera, Foeniculum vulgare and Vaccinium sp. [50].

Known distribution: China, Cuba, Germany, Netherlands, South Africa, United Kingdom, United States, Chile, and Portugal [50]. 

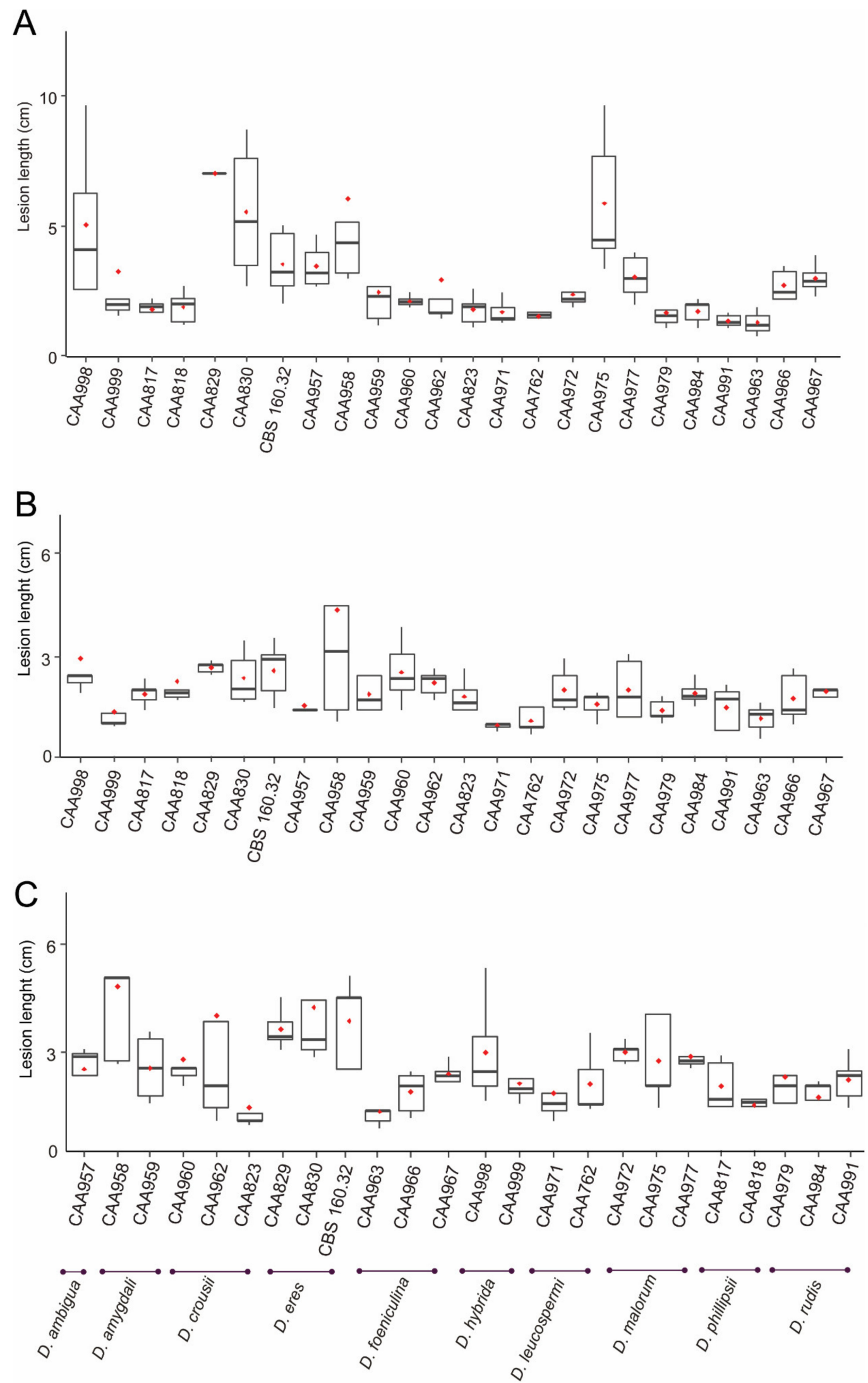

Figure 5. Box plot of lesion length (cm) caused by isolates of Diaporthe on cultivars 'Duke' (A), 'Legacy' (B) and 'Spartan' (C). Medians and means are represented in black lines and red dots, respectively. 

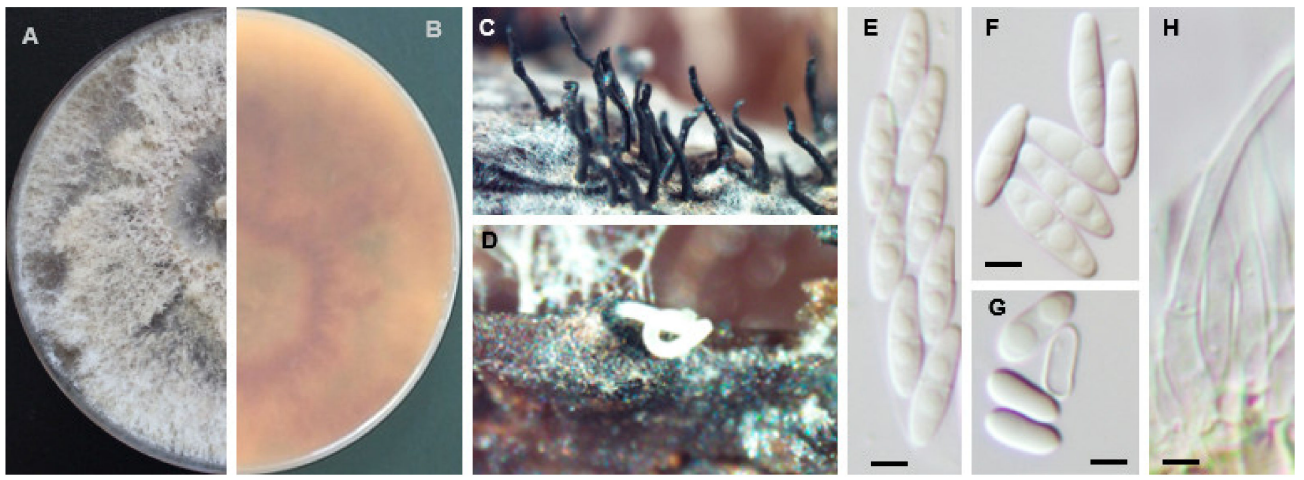

Figure 6. Morphology of Diaporthe ambigua. (A,B)-upper and reverse culture surface, respectively. (C) - Perithecial necks emerging from fennel twigs. (D)-Pycnidia oozing white conidial mass. (E) -8-spored ascus. (F)—Ascospores. (G) - Alpha conidia. (H) —Conidiophores. Bars = $2.5 \mu \mathrm{m}$.

Notes: Diaporthe ambigua was first described on Pyrus communis in Germany, and later on apple, pear and plums in South Africa [51]. Elfar et al. [17], reported for the first time the presence of this fungus on blueberry plants. This study represents the first report of this pathogen on blueberries in Portugal and Europe.

Diaporthe amygdali (Delacr.) Udayanga, Crous \& K.D. Hyde, Fungal Diversity 56: 166 (2012). MycoBank MB 800722.

Specimen examined: Portugal, Aveiro, Arouca, Chave, from diseased twigs of Vaccinium corymbosum, 1 April 2019, P. Pinho, living culture CAA958. Description \& Illustration [52].

Notes: The clade containing the strain CAA958 comprises the ex-type culture of $D$. amygdali isolated from Prunus dulcis, and other synonyms such us $D$. sterilis from $V$. corymbosum, D. kadsurae from Kadsura longipedunculata and D. mediterranea from P. dulcis. Our isolates clustered with a taxon isolated from Vitis vinifera in South Africa. As previously discussed by Hilário et al. [52], this clade represents a single species, D. amygdali.

Diaporthe crousii S. Hilário, L. Santos \& A. Alves, Mycologia 55: 207 (2020). MycoBank MB831439 (Figure 7).
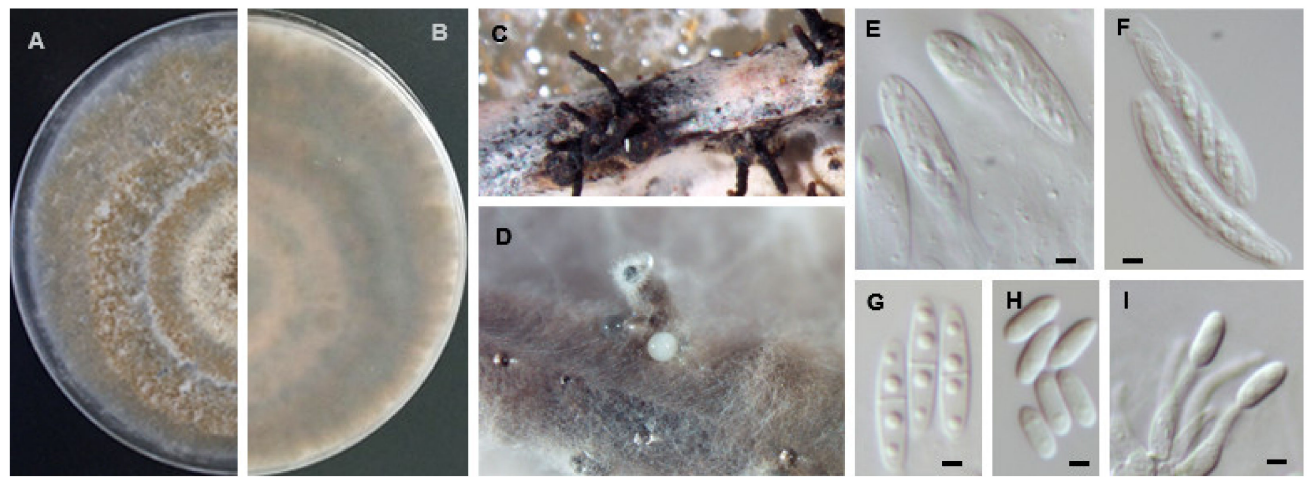

Figure 7. Morphology of Diaporthe crousii. (A,B) - upper and reverse culture surface, respectively. (C) - Perithecial ascomata and necks emerging through pine needles. (D) - White translucid cirri. (E) - Immature asci. (F)—Asci. (G) - Ascospores. (H) - Alpha conidia. (I)—Conidiophores with alpha conidia at their tips. Bars $=2.5 \mu \mathrm{m}$.

Specimen examined: Portugal, Porto, Penafiel, from dead stems of Vaccinium corymbosum, May 2019, H. Moreira, living culture: CAA962.

Sexual morph: Perithecial ascomata globose, solitary or in clusters emerging trough pine needles; brown ascomata necks, tapering towards the apex. Asci 8-spored, unitunicate, clavate to subclavate, straight to slightly curved, (31.0-)34.2-36.8(-41.5) × (4.8-)6.0-6.5(-7.7) $\mu \mathrm{m}$, (mean \pm S.D. $=35.5 \pm 3.0 \times 6.2 \pm 0.7 \mu \mathrm{m}, \mathrm{n}=30$ ). Ascospores hyaline, smooth, septate, frequently tetra-guttulate, ellipsoidal, straight, $(10.5-) 11.0-12.5(-13.3) \times(2.3-) 2.5-3.3(-3.7) \mu \mathrm{m}$, 
$($ mean \pm S.D. $=11.7 \pm 1.0 \times 2.9 \pm 0.6 \mu \mathrm{m}, \mathrm{n}=50)$. Asexual morph: Conidiomata brown to black, extruding white conidial mass. Conidiophores hyaline, aggregated, reduced to conidiogenous cells $(10.5-) 12.8-14.4(-19.0) \times(1.3-) 1.8-2.2(-2.8) \mu \mathrm{m},($ mean \pm S.D. $=13.6$ $\pm 1.9 \times 2.0 \pm 0.4 \mu \mathrm{m}, \mathrm{n}=30)$. Paraphyses not observed. Alpha conidia hyaline, aseptate, ellipsoid, rounded apex and obtuse to truncate base, rarely biguttulate, $(4.6-) 5.5-5.7(-6.2)$ $\times(1.7-) 2.0-2.2(-2.8) \mu \mathrm{m},($ mean \pm S.D. $=5.6 \pm 0.4 \times 2.1 \pm 0.2 \mu \mathrm{m}, \mathrm{n}=100)$. Beta conidia and gamma conidia not observed.

Sexual strategy: homothallism.

Culture characteristics: Colonies on PDA covering a Petri dish after 7 days at $25{ }^{\circ} \mathrm{C}$, spreading with brown to grey sparse aerial mycelium, with reverse greenish to brownish concentric zone.

Host range: Vaccinium corymbosum, Eucalyptus globulus [53].

Known distribution: Portugal.

Notes: Diaporthe crousii was first described as the causal agent of twig canker of blueberries (Vaccinium corymbosum) and associated to Eucalyptus globulus.

Diaporthe foeniculina D. Udayanga \& L. Castlebury, comb. nov. Persoonia 32: 95 (2014). MycoBank MB803929 (Figure 8).

= Diaporthe baccae L. Lombard, G. Polizzi \& P. Crous, Phytopathologia Mediterranea 53: 295 (2014). MycoBank MB807599.

= Diaporthe ravennica Thambugala, Camporesi \& K.D. Hyde, Fungal Diversity 82: 296 (2016). MycoBank MB552100.
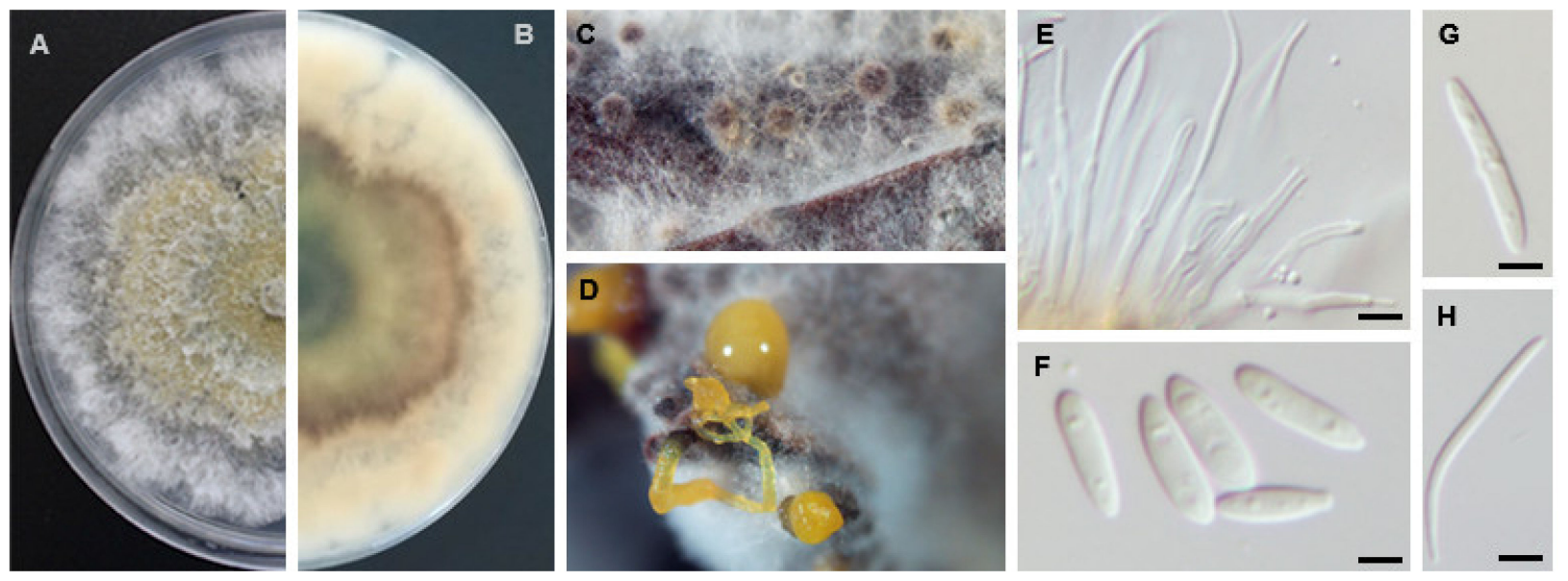

Figure 8. Morphology of Diaporthe foeniculina. (A,B) - upper and reverse culture surface, respectively. (C)—Conidiomata on pine needles. (D)—Pycnidia oozing orange cirri. (E) - Conidiophores with beta conidia at their tips. (F)—Alpha conidia. (G) - Gamma conidia. (H)-Beta conidia. Bars $=2.5 \mu \mathrm{m}$.

Specimen examined: Portugal, Viseu, Mangualde, from twig blight of Vaccinium corymbosum, August 2019, D. Lopes, living culture: CAA967.

Host range: Acacia sp., Achillea millefolium, Ailanthus altissima, Arctium minus, Asparagus sp., Camelia sinensis, Castanea sativa, Citrus aurantiifolia, C. aurantiifolia-limon, C. bergamia, C. japonica, C. latifolia, C. limon, C. lamonia, C. maxima, C. medica, C. mitis, C. paradasi, C. paradisitrifoliata, C. reticulata, C. sinensis, C. sinensis-trifoliata, Corylus avellana, Cupressus sempervirens, Diospyros kaki, Ficus benjamina, F. carica, Foeniculum vulgare, Fuchsia excorticata, Glycine max, Hemerocallis fulva, Juglans regia, Lunaria rediviva, Malus domestica, Melilotus officinalis, Microcitrus australasica, Paraserianthes lophantha, Persea americana, Prunus amygdalus, P. avium, Pyrus communis, P. pyrifolia, Rhus pendulina, Ribes nigrum, Rosa canina, Salix sp., Salvia sp., Tamarix sp., Vaccinium corymbosum, Vicia sp., Vitis vinifera and Wisteria sinensis [50].

Known distribution-Chile, Croatia, France, Germany, Greece, Iran, Italy, Malta, New Zealand, Portugal, Serbia, South Africa, Spain, Turkey, Uruguay, USA [50]. 
Asexual morph: Pycnidial conidiomata, black, erumpent, aggregated or solitary, covered in white mycelium, with yellowish drop-like conidial cirrus oozing from ostiole. Conidiophores hyaline, rarely unbranched, cylindrical, straight to sinuous, reduced to conidiogenous cells, $(10.5-) 12.0-13.9(-15.0) \times(1.4-) 1.8-2.4(-3.0) \mu \mathrm{m},($ mean \pm S.D. $=12.9$ $\pm 1.5 \times 2.1 \pm 0.5 \mu \mathrm{m}, \mathrm{n}=30$ ). Paraphyses not observed. Alpha conidia aseptate, hyaline, smooth, ellipsoidal, frequently with two, rounded apex and rarely with subtruncate base $(6.6-) 7.6-8.2(-9.6) \times(1.8-) 2.3-2.5(-3.0) \mu \mathrm{m},($ mean \pm S.D. $=7.9 \pm 0.7 \times 2.4 \pm 0.3 \mu \mathrm{m}$, $\mathrm{n}=100$ ). Beta conidia hyaline, aseptate, eguttulate, slightly curved, abundant, apex acute, base subtruncate, $(20.5-) 21.5-23.4(-26.9) \times(0.9-) 1.2-1.4(-1.8) \mu \mathrm{m},($ mean \pm S.D. $=22.4$ $\pm 1.9 \times 1.3 \pm 0.3 \mu \mathrm{m}, \mathrm{n}=100)$. Gamma conidia rare, aseptate, hyaline, rounded apex, $(11.9-) 11.6-13.0(-13.1) \times(1.6-) 1.7-1.9(-2.0) \mu \mathrm{m},($ mean \pm S.D. $=12.3 \pm 0.7 \times 1.8 \pm$ $0.2 \mu \mathrm{m}, \mathrm{n}=4)$. Sexual morph: not observed.

Sexual strategy: heterothallism.

Culture characteristics: colonies on PDA at $25^{\circ} \mathrm{C}$ after 7 days spreading moderate with aerial mycelium, feathery margins, pale brown zones in a radial pattern and reverse with greenish yellow pigmentation developing in the centre.

Notes: Phillips \& Santos [29] described Diaporthe neotheicola in Portugal from Foeniculum vulgare. Later, Udayanga \& Castlebury [54] synonymized D. neotheicola as D. foeniculina and that is the name currently accepted. Posterior to that, Thambugala, Camporesi \& Hyde [55] described D. ravennica as a distinct species phylogenetically distinct from $D$. baccae and D. foeniculina. Here we show that $D$. foeniculina and D. baccae cluster in a wellsupported clade and are closely related. A pairwise comparison showed that $D$. foeniculina and $D$. baccae are similar, since both species differ in $7 \mathrm{nt}$ in ITS ( $p$-distance $=0.012), 2 \mathrm{nt}$ of his3 $(p$-distance $=0.004)$ and 1 in cal $(p$-distance $=0.002)$. Tef1- $\alpha$ and tub2 sequences from both $D$. foeniculina and D. baccae are $100 \%$ identical.

Moreover, in the ITS initial tree performed, we noted that $D$. ravennica was very closely related to $D$. foeniculina and D. baccae. Due to the absence of cal and his3 sequences, we could not include the species in our phylogenetic analysis. However, we noted that $D$. ravennica is $100 \%$ identical to $D$. baccae and D. foeniculina based on tef1- $\alpha$ and tub2 loci, and $9 \mathrm{nt}(p$-distance $=0.015)$ and $3 \mathrm{nt}(p$-distance $=0.005)$ in the ITS locus separate $D$. ravennica from $D$. foeniculina and $D$. baccae respectively. Morphologically, these species are virtually indistinguishable with overlapping micromorphological characters: yellow to pale luteous conidial cirrhus; alpha conidia with base subtruncate, with none, two or many guttules; beta conidia curved, base subtruncate, acute apex and with dimensions matching within the same ranges.

Diaporthe leucospermi P. Crous \& B. Summerell, Persoonia 27: 32 (2011). MycoBank MB560561 (Figure 9).
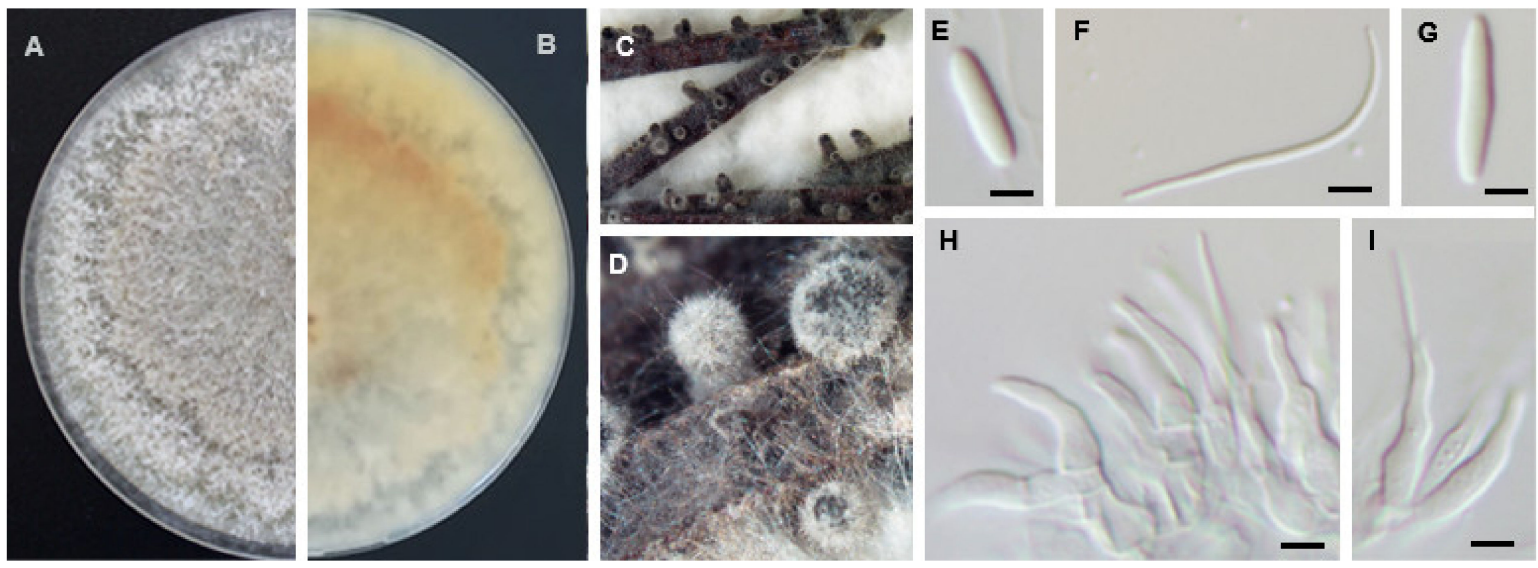

Figure 9. Morphology of Diaporthe leucospermi. (A,B)—upper and reverse culture surface, respectively. (C,D)—Conidiomata on pine needles. (E) - Alpha conidia. (F)—Beta conidia. (G) - Gamma conidia. (H) - Conidiophores arising from pseudoparenchyma. (I) - Conidiophores with beta conidia at their tip. Bars $=2.5 \mu \mathrm{m}$. 
= Diaporthe pyracanthae L. Santos \& A. Alves, Mycosphere 8: 489 (2017). MycoBank MB820224.

= Diaporthe rossmaniae S. Hilário, I. Amaral, L. Santos \& A. Alves, Mycologia 55: 207 (2020). MycoBank MB831452.

Specimen examined: Portugal, Porto, Agrela, from a dead twig of Vaccinium corymbosum, July 2019, S. Hilário, living culture: CAA971.

Host range: Acer negundo, Chamaerops humilis, Hydrangea macrophylla, Leucospermum sp., Pyracantha coccinea, Vaccinium corymbosum [50].

Known distribution: Australia and Portugal [50].

Asexual morph: Pycnidial conidiomata, brown to black, embedded on fennel stems and pine needles, aggregated or solitary, covered in white mycelium, oozing white translucid conidial cirrhus. Conidiophores subcylindrical, aseptate, branched, reduced to conidiogenous cells, sometimes bearing beta conidia at their tips $(9.9-) 10.8-14.1(-15.2) \times$ $(1.5-) 1.6-2.6(-3.1) \mu \mathrm{m},($ mean \pm S.D. $=12.5 \pm 2.1 \times 2.1 \pm 0.6 \mu \mathrm{m}, \mathrm{n}=30)$. Paraphyses not observed. Alpha conidia hyaline, ellipsoid, found infrequent, eguttulate, rounded apex and obtuse base, $(4.4-) 4.9-5.8(-5.9) \times(1.7-) 1.9-2.6(-2.3) \mu \mathrm{m},($ mean \pm S.D. $=5.4 \pm 0.6$ $\times 2.1 \pm 0.2 \mu \mathrm{m}, \mathrm{n}=10)$. Beta conidia hyaline, aseptate, smooth, filiform, hooked in apical part, apex acute, base truncate, $(22.5-) 26.1-28.5(-31.8) \times(1.0-) 1.1-1.3(-1.5) \mu \mathrm{m}$, (mean \pm S.D. $=27.3 \pm 2.9 \times 1.2 \pm 0.2 \mu \mathrm{m}, \mathrm{n}=100)$. Gamma conidia infrequent, aseptate, hyaline, rounded apex, $(8.1-) 7.7-9.1(-8.8) \times(1.8-) 1.9-2.0(-2.1) \mu \mathrm{m},($ mean \pm S.D. $=8.4 \pm 0.5 \times$ $2.9 \pm 0.1 \mu \mathrm{m}, \mathrm{n}=4)$. Sexual morph: not observed

Sexual strategy: heterothallism.

Culture characteristics: colonies on PDA at $25{ }^{\circ} \mathrm{C}$ after 7 days spreading large with moderate aerial mycelium, pale olivaceous-grey to smoke-grey with patches of olivaceous black near the margins; reverse straw yellow with gallstone yellow zones.

Notes: Crous \& Summerell [56] described Diaporthe leucospermi on leaves of Leucospermum sp. in Australia. Santos et al. [57] described D. pyracanthae from Malus domestica in Portugal as a distinct species based on multi-gene phylogenetic analyses and morphological characters. These authors have shown that despite the similarities of conidial dimensions between both species, they differ in several nucleotide positions: three nucleotides in ITS, $1 \mathrm{nt}$ in tef1- $\alpha, 8 \mathrm{nt}$ in tub2 and $2 \mathrm{nt}$ in his3. Later, Hilário et al. [8] described D. rossmaniae as a distinct but closely related species to $D$. pyracanthae and $D$. leucospermi. The authors have shown that although culture characteristics are slightly different, alpha and beta conidia dimensions are within the same ranges. Moreover, $D$. rossmaniae differs from $D$. leucospermi in $3 \mathrm{nt}$ in ITS, 3 in tef1- $\alpha, 2 \mathrm{nt}$ in his3 and 1 in tub2 and from D. pyracanthae in five nucleotides in $t u b 2$ and 2 in tef1- $\alpha$ [8]. However, we show in this study that $D$. rossmaniae is phylogenetically indistinguishable from $D$. pyracanthae and D. leucospermi.

Diaporthe malorum L. Santos \& A. Alves, Mycosphere 8: 489 (2017). MycoBank MB820226. Specimen examined: Portugal, Aveiro, Arouca, on twigs of Vaccinium corymbosum, January 2020, S. Hilário, living culture: CAA972, CAA974. Description \& Illustration [58].

Host range: Malus domestica [57], Eucalyptus globulus [53], Vaccinium corymbosum.

Known distribution: Portugal.

Notes: The clade comprising Diaporthe malorum firstly described as the causal agent of twig canker and shoot blight of apples (Malus domestica), also contains isolates from E. globulus and V. corymbosum.

Diaporthe rudis (Fr.) Nitschke, Pyrenomycetes Germanici 2: 282 (1870). (Figure 10). Specimen examined: Portugal, Porto, Arcozelo, from twig blight symptoms of Vaccinium corymbosum, July 2019, S. Hilário, living culture: CAA991. 

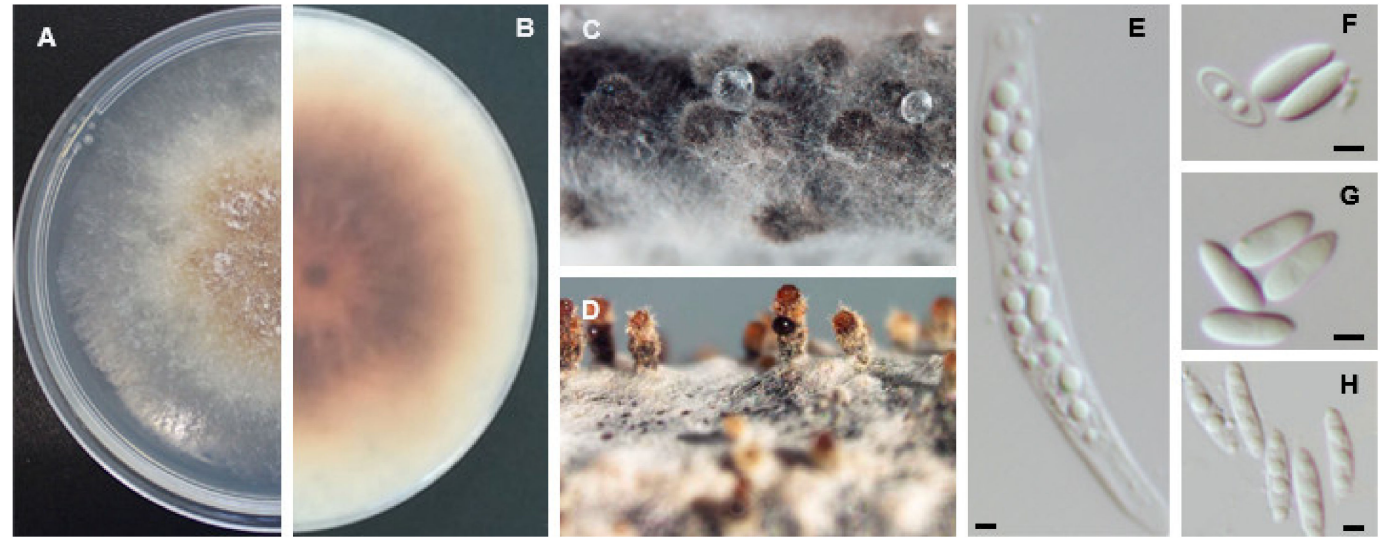

Figure 10. Morphology of Diaporthe rudis. (A,B)—upper and reverse culture surface, respectively. (C) —Conidiomata on pine needles. (D)—Perithecial ascomata on fennel twigs. (E)—Ascus. (F,G)—Alpha conidia. $(\mathbf{H})$-Ascospores. Bars $=2.5 \mu \mathrm{m}$.

Sexual morph: Perithecial ascomata globose, solitary or in clusters. Perithecial necks brown to black, covered in white mycelium. Asci unitunicate elongate, 8-spored, (48.0-)49.2 $-53.5(-57.6) \times(5.8-) 6.0-6.6(-6.9) \mu \mathrm{m},($ mean \pm S.D. $=51.3 \pm 3.1 \times 6.3 \pm 0.4 \mu \mathrm{m}, \mathrm{n}=$ 10). Ascospores hyaline, elongated, septate, frequently tetra-guttulate with larger guttules at center, $(9.7-) 11.4-11.9(-13.2) \times(2.1-) 2.7-2.9(-3.6) \mu \mathrm{m},($ mean \pm S.D. $=11.6 \pm 0.8 \times$ $2.8 \pm 0.3 \mu \mathrm{m}, \mathrm{n}=50$ ). Asexual morph: Conidiomata brown, erumpent from fennel stems, extruding white conidial mass. Conidiophores not observed. Paraphyses not observed. Alpha conidia ellipsoidal, biguttulate, with an obtuse apex and rounded at the other end, $(5.4-) 6.1-6.3(-7.0) \times(2.1-) 2.5-2.6(-2.9) \mu \mathrm{m},($ mean \pm S.D. $=6.2 \pm 0.3 \times 2.5 \pm 0.2 \mu \mathrm{m}$, $\mathrm{n}=100)$. Beta and gamma conidia not observed.

Sexual strategy: homothallism.

Culture characteristics: In dark at $25^{\circ} \mathrm{C}$ for seven days, colonies on PDA relatively slow growing, white to pale brown zones developing in centre, aerial mycelium, reverse with reddish concentric zones.

Host range: Acer sp., Asphodelus albus, Aucuba japonica, Brugmansia sp., Castanea sp., Corylus sp., Dipsacus fullonum, Epilobium sp., Eucalyptus globulus, Fagus sp., Fraxinus sp., Holcus sp., Hydrangea sp., Ileostylis sp., Laburnum sp., Lupinus sp., Malus sp., Protea sp., Pyrus sp., Rosa sp., Sambucus sp., Salix sp., Vaccinium corymbosum and Vitis vinifera [50].

Known distribution: Australia, Canada, Chile, Austria, Germany, Italy, Latvia, Portugal, Spain, Sweden, Switzerland, New Zealand and South Africa [50].

Notes: Diaporthe rudis, commonly associated to Vitis vinifera, it has been reported on a wide range of hosts including blueberries. Compared with the description of Udayanga et al. [54], our isolate CAA991 has shorter and thinner ascospores $(11.6 \pm 0.8 \times 2.8 \pm 0.3 \mu \mathrm{m}$ vs 13.2 $\pm 1.1 \times 3.6 \pm 0.1 \mu \mathrm{m})$, and longer conidiogenous cells. Besides that, beta conidia of isolate CAA991 were not found, whereas it was reported in the ex-type CBS 113201.

Diaporthe hybrida S. Hilário \& A. Alves, Fungal Biology (in press) 2021. MycoBank: MB838688.

Specimen examined: Portugal, Santarém, Ourém, on twigs of Vaccinium corymbosum, January 2020, S. Hilário, living culture: CAA998 (MUM 21.01). Description \& Illustration [58].

Notes: Diaporthe hybrida was the first hybrid described in this genus [58], from cross between D. portugallica [59] and D. phillipsii [8].

\section{Discussion}

Although a previous study identified a few species of Diaporthe as causal agents of twig blight and dieback diseases in the major blueberry production in central Portugal [8], the current study represents the first national survey to evaluate the distribution of Diaporthe on several blueberry cultivars. Additionally, this study also gives an insight into the pathogenicity potential of Diaporthe species, including the well-known pathogen $D$. vaccinii, to some blueberry cultivars planted in Portugal. 
Diaporthe foeniculina (formerly known as Phomopsis theicola and D. neotheicola) was first described on Camellia sinensis in Italy in 1927 [29], and since then it has been isolated from several hosts such as Vitis vinifera, Protea sp., Pyrus sp., Citrus sp. [13,60,61], Aspalathus linearis [62], Foeniculum vulgare [29] and Prunus sp. [63]. Later, Elfar et al. [17] reported the presence of $D$. foeniculina in Chile for the first time, noting that it caused stem cankers on blueberries. Hilário et al. [8] also found D. foeniculina occurring as endophyte or latent pathogen in asymptomatic branches and from dead plant material co-existing with $D$. rudis. The pathogenicity testes carried out by Elfar et al. [17] and Hilário et al. [8] showed that although causing cankers, it is reasonable to consider $D$. foeniculina as a weak pathogen on Vaccinium corymbosum plants.

Diaporthe rudis, (referred to as D. viticola) is a well-known pathogen in Europe and New Zealand mostly associated to Vitis vinifera [11,54]. This fungus has also been found on a wide range of hosts such as Aucuba japonica, Fraxinus excelsior, Citrus sp., Acer sp., and Castanea sativa and distributed worldwide [13]. Despite the presence of D. rudis on blueberry plants in the Netherlands [2], it is unclear whether the species was obtained from diseased or healthy plants or if pathogenicity tests were performed. On the contrary, Cardinaals et al. [7] also isolated D. rudis in the Netherlands from blueberries with shoot blight, whereas Hilário et al. [8] isolated this species from diseased and asymptomatic plants. The present study records, for the second time, the occurrence of $D$. rudis on $V$. corymbosum in Portugal. Although it was the most dominant species found (38.8\%), it may be claimed that the presence of $D$. rudis on blueberry just occurred as a result of high inoculum pressure, given that most of the blueberry plantations were located close to vineyards. Moreover, a recent study demonstrated that $D$. rudis caused minor symptoms on blueberry plants after artificial inoculations [8]. Taking all of this into consideration, this raises questions about the real impact of this species on blueberries, suggesting that $D$. rudis may be less prone to be a pathogen on blueberries.

Diaporthe ambigua was firstly described on Pyrus communis in Germany, and later on apple, pear and plums in South Africa [51]; In 2009, this species was isolated from Foeniculum vulgare in Portugal [29]; on grapevines in California and on blueberry plants in Chile around 2013 [17,64], and most recently, in 2019, D. amygdali was isolated from kiwi fruits in Greece [65]. Although D. ambigua has been claimed to be virulent in shoots, stems, and fruit of blueberries [17] the records of this pathogen on blueberries are limited and unclear. In the present study, D. ambigua was recovered from one orchard only. Moreover, in a recent study, Spies et al. [66] investigated twigs of 145 European olive trees in South Africa showing dieback and found that D. ambigua was only recovered from a single European olive tree, and that its pathogenicity to this host was unknown. This occasional occurrence of D. ambigua on olives in South Africa and blueberries in Portugal, allied to the fact that this species has been found on blueberry dead stems, raises the possibility of a saprophytic behaviour of D. ambigua. Such a conclusion was previously drawn by Santos \& Phillips [29], who proposed that D. ambigua may be purely saprophytic, taking advantage of dead plant material to grow.

Diaporthe leucospermi was first described from leaves of Leucospermum sp. in Australia in 2012 [51] and, since then, no records of this species have been documented. However, Santos et al. [15] collected the isolates Ph-C189/1, Ph-C180/1, Ph-C174/1 and Di-C007 from Hydrangea macrophylla and Acer negundo in Portugal. It is worthy to note that based on ITS and tef1- $\alpha$ available sequences, these isolates are deemed to fall within the concept of $D$. leucospermi. A pairwise comparison revealed that the Portuguese isolates are $100 \%$ identical to $D$. leucospermi in the ITS region, whereas some polymorphisms are shared among these isolates in tef1- $\alpha$ locus. Only two nucleotide differences and the presence of a $7 \mathrm{bp}$ insertion (5' CCCCCCC $3^{\prime}$ ) in tef1- $\alpha$ region of isolates Ph-C189/1 and Di-C007 separate them from D. leucospermi, while no polymorphisms were observed among isolates $\mathrm{Ph}-\mathrm{C} 180 / 1$ and $\mathrm{Ph}-\mathrm{C} 174 / 1$ and D. leucospermi. However, further studies including other loci would be required to resolve the identity of the Portuguese isolates mentioned above. Later, Santos et al. [57] and Hilário et al. [8] described D. 
pyracanthae and D. rossmaniae as two different species, but they are shown in this study to be indistinguishable from $D$. leucospermi.

The distribution of Diaporthe malorum is only known from Portugal, where it was found in M. domestica [57] and E. globulus [53]. The present study is the first to report the presence of this species in blueberries. Diaporthe crousii, firstly described as a pathogen on V. corymbosum in Portugal [8], was also found in E. globulus [53].

Diaporthe amygdali (=Phomopsis amygdali), has been reported worldwide on a wide variety of hosts [67]. In a recent study, a monophyletic clade containing D. amygdali and closely related species was resolved by applying the principle of Genealogical Concordance Phylogenetic Species Recognition and the coalescent-based species delimitation methods [52]. Apart from the report of D. sterilis (syn. D. amygdali) causing cankers and twig blight on Vaccinium corymbosum in Italy [2], the present study reports for the second time the presence of $D$. amygdali associated with twig blight of blueberry plants.

Diaporthe hybrida, described as the first hybrid in the genus Diaporthe [58] was also pathogenic to blueberry, but the prevalence of this species in the survey was low, given that its presence was restricted to one plantation only (Ourém). Therefore, the impact of this new hybrid pathogen on blueberry orchards remains unclear.

Pathogenicity trials were carried out using nine-month-old blueberry plants, unveiling the capacity of Diaporthe to cause lesions on this crop. All Diaporthe species inoculated to blueberry plants cv. 'Duke', 'Legacy' and 'Spartan' were able to cause lesions. The most severe symptoms were found on blueberry twigs inoculated with D. eres (CAA829) in the cultivar 'Duke', which caused the death of all replicates. Diaporthe hybrida was also found to cause necrosis when inoculated in cultivar Duke. It is noteworthy that this species was able to cause significantly larger lesions than its parental species (D. phillipsii) [58], which is corroborated by studies that state that hybrids are thought to be important for the evolution of fungal plant pathogens, increasing their virulence on the host [68]. Given that hybridization plays a crucial role in the spread of pathogenicity traits, further genetic analysis of $D$. hybrida would be essential to establish new insights into the impact of this new virulent pathogen, which may affect blueberry plants. Lombard et al. [2] have shown that D. sterilis (syn. D. amygdali) caused brown lesions developing on the green stems and twigs, resulting in twig blight on cultivar 'Legacy'. Likewise, in the present study, the isolate CAA958 (D. amygdali) not only caused mortality of one out of five replicates in the cultivar 'Legacy', but it also caused the longest lesions in this cultivar, when compared to the other Diaporthe species. Overall, D. amygdali and D. eres showed to be one of the most virulent species, while D. ambigua, D. foeniculina, D. rudis and D. leucospermi yielded the smallest lesion lengths and were thus regarded as the least aggressive species.

Although Diaporthe vaccinii was earlier considered as a quarantine pathogen for the European Union (EU Regulation 2016/2031), the recent EU Regulation (2019/2072) does not include the species in the current list of EU quarantine pests. However, the impact and pathogenicity potential of $D$. vaccinii was never entirely explored. [18]. It is worthy to note that $D$. vaccinii was not found during our survey across the country, and no records have been reported in Europe in the past few years [69]. Nabetani et al. [23] have shown that $D$. vaccinii might be the major causal agent of twig blight on blueberry plants in British Colombia and found that the cultivar 'Duke' was shown to be more susceptible to D. vaccinii. Contrarily, Cardinaals et al. [7] tested D. vaccinii on cultivars 'Duke' and 'Liberty' but revealed that the symptoms caused by this pathogen are insignificant, and thus it may not represent a major threat to commercial blueberry productions. Currently, it is known that it has been eradicated from all European countries where it was earlier detected [70]. This can also be a proof that $D$. vaccinii might have been wrongly identified, as also suggested by Lombard et at. [2] and Elfar et al. [17], as its identification was previously based on its Phomopsis-like conidia and host association. According to our pathogenicity tests, the cultivar 'Duke' was the most susceptible to D. eres infection. Moreover, we also demonstrated that D. eres strain CBS 160.32 (syn. D. vaccinii) caused similar lesion lengths to $D$. eres strains CAA829 and CAA830, and it was not aggressive, as has been recurrently 
described in the literature. Such results corroborate the hypothesis that $D$. vaccinii is a synonym of $D$. eres, and that this species not only harbours intraspecific variability [20] but also differences in virulence among isolates. Furthermore, it is noteworthy that the pathogenicity trials carried out in this study were based solely on one strain of $D$. vaccinii (ex-type CBS 160.32). This strain has been kept in culture for over 90 years, which might have affected its virulence, leading to loss of its pathogenicity. Therefore, this study provides evidence about the capability of $D$. eres to cause disease on $V$. corymbosum, which is more aggressive than the well-known host-specific strain CBS 160.32. As previously suggested by Cardinaals et al. [7] and supported by our results, the strain CBS 160.32 might not represent a threat to blueberry orchards in Europe.

It is also worth mentioning that the Diaporthe species identified in this study were found to be co-existing in the same plant material with members of Botryosphaeriaceae and Pestalotiopsis. Such an occurrence is not new, as it has been previously reported $[17,71-73]$. This should not be overlooked, and it deserves further investigation, given that the species of Diaporthe, together with other pathogenic fungi [74], may contribute to cause dieback and twig blight of blueberries.

\section{Conclusions}

The present study is the first to assess Diaporthe species associated with blueberries from several orchards in Portugal, combining morphology and molecular data, which provide useful information to evaluate the pathogenicity potential of several species in different blueberry cultivars. To our knowledge, this study is the first to report of $D$. leucospermi, D. amygdali and D. malorum associated with blueberries, and of D. ambigua on this host in Europe. We have also demonstrated that strain CBS 160.32 (D. eres) did not cause the death of any plant inoculated, and that the symptoms caused were minor, when compared to other isolates, indicating that this strain may not be a threat to Vaccinium plantations. However, it is important to highlight that $D$. amygdali and with D. eres (strains CAA829 and CAA830) are the most aggressive species, indicating the importance of $D$. eres as a pathogen of blueberries. Moreover, pathogenicity studies coupled with morphophysiological and biochemical parameters will be essential to clarify the pathogenic role and the impact of Diaporthe on the physiology of blueberry.

Supplementary Materials: The following are available online at https: / www.mdpi.com/article / 10.3390/agriculture11121271/s1, Figures S1-S5: Phylogram generated from Maximum Likelihood analysis based on ITS, tef1- $\alpha, t u b 2$, cal and his3 sequence data from Diaporthe, respectively. Figure S6: Box plot of lesion length $(\mathrm{cm})$ caused by Diaporthe species. Figures S7-S9: Time course percentage of mortality of 'Duke', 'Legacy' and 'Spartan' cultivars, respectively. Table S1: Cases of Diaporthe species found alone or co-existing $(+)$ with other species.

Author Contributions: Conceptualization, S.H., L.S. and A.A.; Methodology, S.H., L.S. and A.A.; Formal Analysis, S.H.; Investigation, S.H.; Resources, A.A.; Writing-original draft preparation, S.H.; Writing-review and editing, S.H., L.S. and A.A.; Supervision, A.A. and L.S.; Funding acquisition, A.A. All authors have read and agreed to the published version of the manuscript.

Funding: This research was funded by the Portuguese Foundation for Science and Technology (FCT/MCTES) for financing CESAM (Centre for Environmental and Marine Studies) (UIDP/50017/2020 + UIDB/50017/2020) through national funds, and the PhD grants of Sandra Hilário (SFRH/BD/137394/2018). Liliana Santos is funded by national funds (OE), through FCT in the scope of the framework contract foreseen in the numbers 4, 5 and 6 of the article 23, of the Decree-Law 57/2016, of August 29, changed by Law 57/2017, of July 19.

Institutional Review Board Statement: Not applicable.

Informed Consent Statement: Not applicable.

Data Availability Statement: All data generated and analysed in this study are included in this article and its Supplementary Materials. All sequence data are available in the NCBI GenBank, following the accession numbers in the manuscript. 
Acknowledgments: The authors are thankful to Portuguese producers for supplying the plant material from their plantations: Hugo Botelho and Pedro Pinho (Bfruit Nature Flavors), Hugo Lains (WePlant in Portugal), Nuno Silveira (Visionagro, Lda), Helder Moreira (Valxisto, Unipessoal, Lda), Jorge Duarte, João Vieira, António Rodrigues, Ana Moreira (Hortitool Consulting, Lda), Marcelo Miranda and Mónica (Groselh\&Mirtilo), Rui Marinho (Quinta da Hortelã), Odete Gonçalves (Bluepanoply), Diana Lopes and Mara Almeida (Acegrow), and Paulo. We want also to thank Eduardo Batista (University of Aveiro) for helping with the inoculation of plants.

Conflicts of Interest: The authors declare no conflict of interest.

\section{References}

1. Retamales, J.B.; Hancock, J.F. Blueberries; CAB International: London, UK, 2012; p. 323.

2. Lombard, L.; Van Leeuwen, G.C.M.; Guarnaccia, V.; Polizii, G.; Van Rijswick, P.C.J.; Rosendahl, C.H.M.; Gabler, J.; Crous, P.W. Diaporthe species associated with Vaccinium, with specific reference to Europe. Phytopathol. Mediterr. 2014, 53, $287-299$.

3. Gonçalves, C.; Guiné, R.P.F.; Teixeira, D.; Gonçalves, F.J. Evaluation of bioactive phenols in blueberries from different cultivars. Int. J. Biol. Food Vet. Agric. Eng. 2015, 9, 281-284.

4. Silva, S.; Costa, E.M.; Veiga, M.; Morais, R.M.; Calhau, C.; Pintado, M. Health promoting properties of blueberries: A review. Crit. Rev. Food Sci. Nutr. 2020, 60, 181-200. [CrossRef] [PubMed]

5. Food and Agriculture Organization of the United Nations (FAOSTAT). Available online: http://www.fao.org/faostat/en/\#home (accessed on 30 May 2021).

6. Portal do Instituto Nacional de Estatística. Estatísticas agrícolas 2020 (INE). Available online: https://www.ine.pt/xurl/pub/43 7147278 (accessed on 10 July 2021).

7. Cardinaals, J.; Wenneker, M.; Voogd, J.G.B.; van Leeuwen, G.C.M. Pathogenicity of Diaporthe spp. on two blueberry cultivars (Vaccinium corymbosum). EPPO Bull. 2018, 48, 128-134. [CrossRef]

8. Hilário, S.; Amaral, A.I.; Gonçalves, M.F.M.; Lopes, A.; Santos, L.; Alves, A. Diaporthe species associated with twig blight and dieback of Vaccinium corymbosum in Portugal, with description of four new species. Mycologia 2020, 112, 293-308. [CrossRef]

9. Rodríguez-Gálvez, E.; Hilário, S.; Lopes, A.; Alves, A. Diversity and pathogenicity of Lasiodiplodia and Neopestalotiopsis species associated with stem blight and dieback of blueberry plants in Peru. Eur. J. Plant Pathol. 2020, 157, 89-102. [CrossRef]

10. Scarlett, K.A.; Shuttleworth, L.A.; Collins, D.; Rothwell, C.T.; Guest, D.I.; Daniel, R. Botryosphaeriales associated with stem blight and dieback of blueberry (Vaccinium spp.) in New South Wales and Western Australia. Australas. Plant Pathol. 2018, 48, 45-57. [CrossRef]

11. Guarnaccia, V.; Groenewald, J.Z.; Woodhall, J.; Armengol, J.; Cinelli, T.; Eichmeier, A.; Ezra, D.; Fontaine, F.; Gramaje, D.; Gutierrez-Aguirregabiria, A.; et al. Diaporthe diversity and pathogenicity revealed from a broad survey of grapevine diseases in Europe. Persoonia 2018, 40, 135-153. [CrossRef]

12. Udayanga, D.; Liu, X.; McKenzie, E.H.C.; Chukeatirote, E.; Bahkali, A.H.A.; Hyde, K.D. The genus Phomopsis: Biology, applications, species concepts and names of common phytopathogens. Fungal Divers. 2011, 50, 189-225. [CrossRef]

13. Gomes, R.R.; Glienke, C.; Videira, S.I.R.; Lombard, L.; Groenewald, J.Z.; Crous, P.W. Diaporthe: A genus of endophytic, saprobic and plant pathogenic fungi. Persoonia 2013, 31, 1-41. [CrossRef] [PubMed]

14. Mathew, F.M.; Olson, T.R.; Science, P.; Dakota, S. Identification of sunflower (Helianthus annuus) accessions resistant to Diaporthe helianthi and Diaporthe gulyae. Plant Health Prog. 2018, 19, 97-102. [CrossRef]

15. Santos, J.M.; Correia, V.G.; Phillips, A.J.L. Primers for mating-type diagnosis in Diaporthe and Phomopsis: Their use in teleomorph induction in vitro and biological species definition. Fungal Biol. 2010, 114, 255-270. [CrossRef]

16. Yang, Q.; Fan, X.-L.; Guarnaccia, V.; Tian, C.-M. High diversity of Diaporthe species associated with dieback diseases in China, with twelve new species described. MycoKeys 2018, 39, 97-149. [CrossRef] [PubMed]

17. Elfar, K.; Torres, R.; Díaz, G.A.; Latorre, B. Characterization of Diaporthe australafricana and Diaporthe spp. associated with stem canker of blueberry in Chile. Plant Dis. 2013, 97, 1042-1050. [CrossRef]

18. Van Bruggen, A.H.C.; West, J.S.; van der Werf, W.; Potting, R.P.J.; Gardi, C.; Koufakis, I.; Zelenev, V.V.; Narouei-Khandan, H.; Shilder, A.; Harmon, P. Input data needed for a risk model for the entry, establishment and spread of a pathogen (Phomopsis vaccinii) of blueberries and cranberries in the EU. Ann. Appl. Biol. 2018, 172, 126-147. [CrossRef]

19. Farr, D.F.; Castlebury, L.A.; Rossman, A.Y. Morphological and molecular characterization of Phomopsis vaccinii and additional isolates of Phomopsis from blueberry and cranberry in the eastern United States. Mycologia 2002, 94, 494-504. [CrossRef] [PubMed]

20. Hilário, S.; Gonçalves, F.M.; Alves, A. Using genealogical concordance and coalescent-based species delimitation to assess species boundaries in the Diaporthe eres complex. J. Fungi 2021, 7, 507. [CrossRef]

21. Sessa, L.; Abreo, E.; Lupo, S. Diversity of fungal latent pathogens and true endophytes associated with fruit trees in Uruguay. J. Phytopathol. 2018, 166, 633-647. [CrossRef]

22. Weingartner, D.P.; Klos, E.J. Etiology and symptomatology of canker and dieback diseases on blueberry caused by Fusicoccum and Diaporthe. Phytopathology 1975, 65, 105-110. [CrossRef]

23. Nabetani, K.; Wood, B.K.; Sabaratnam, S. Role of pycnidia in twig and blossom blight and stem dieback of highbush blueberry caused by Phomopsis vaccinii in British Columbia. Can. J. Plant Pathol. 2017, 39, 405-421. [CrossRef] 
24. Vilka, L.; Volkova, J. Morphological diversity of Phomopsis vaccinii isolates from cranberry (Vaccinium macrocarpon Ait.) in Latvia. Proc. Latv. Univ. Agric. 2015, 33, 8-18. [CrossRef]

25. Madeira, B.S.P. Cultura do Mirtilo; Agrobook: Lisbon, Portugal, 2016; p. 200.

26. Syme, P. Werner's Nomenclature of Colours. A Recreation of the Original 1821 Color Guidebook with New Cross References, Photographic Examples, and Posters Designed by Nicholas Rougeux. Available online: https://www.c82.net/werner/ (accessed on 21 April 2021).

27. Möller, E.M.; Bahnweg, G.; Sandermann, H.; Geiger, H.H. A simple and efficient protocol for isolation of high molecular weight DNA from filamentous fungi, fruit bodies, and infected plant tissues. Nucleic Acids Res. 1992, 20, 6115-6116. [CrossRef] [PubMed]

28. Alves, A.; Phillips, A.J.L.; Henriques, I.; Correia, A. Rapid differentiation of species of Botryosphaeriaceae by PCR fingerprinting. Res. Microbiol. 2007, 158, 112-121. [CrossRef]

29. Santos, J.M.; Phillips, A.J.L. Resolving the complex of Diaporthe (Phomopsis) species occurring on Foeniculum vulgare in Portugal. Fungal Divers. 2009, 34, 111-125.

30. White, T.J.; Bruns, T.; Lee, S.; Taylor, J. Amplification and direct sequencing of fungal ribosomal RNA genes for phylogenetics. In PCR Protocols: A Guide to Methods and Applications; Innis, M.A., Gelfand, D.H., Sninsky, J.J., White, T.J., Eds.; Academic Press: San Diego, CA, USA, 1990; pp. 315-322.

31. Alves, A.; Correia, A.; Luque, J.; Phillips, A.J.L. Botryosphaeria corticola sp. nov. on Quercus species, with notes and description of Botryosphaeria stevensii and its anamorph, Diplodia mutila. Mycologia 2004, 96, 598-613. [CrossRef]

32. Alves, A.; Crous, P.W.; Correia, A.; Phillips, A.J.L. Morphological and molecular data reveal cryptic speciation in Lasiodiplodia theobromae. Fungal Divers. 2008, 28, 1-13.

33. Glass, N.L.; Donaldson, G.C. Development of primer sets designed for use with the PCR to amplify conserved genes from filamentous Ascomycetes. Appl. Environ. Microbiol. 1995, 61, 1323-1330. [CrossRef]

34. O'Donnell, K.; Cigelnik, E. Two divergent intragenomic rDNA ITS2 types within a monophyletic lineage of the fungus Fusarium are nonorthologous. Mol. Phylogenet. Evol. 1997, 7, 103-116. [CrossRef] [PubMed]

35. Carbone, I.; Kohn, L.M. A method for designing primer set for speciation studies in filamentous ascomycetes. Mycologia 1999, 91, 553-556. [CrossRef]

36. Crous, P.W.; Groenewald, J.Z.; Risede, J.M.; Hywe, N.L. Calonectria species and their Cylindrocladium anamorphs: Species with sphaeropedunculate vesicles. Stud. Mycol. 2004, 50, 415-430.

37. Larkin, M.A.; Blackshields, G.; Brown, N.P.; Chenna, R.; McGettigan, P.A.; McWilliam, H.; Higgins, D.G. Clustal W and Clustal X version 2.0. Bioinformatics 2007, 23, 2947-2948. [CrossRef] [PubMed]

38. Hall, T.A. BioEdit: A user-friendly biological sequence alignment editor and analysis program for Windows 95/98/NT. Nucleic Acids Symp. Ser. 1999, 41, 95-98.

39. Vaydia, G.; Lohman, D.J.; Meier, R. SequenceMatrix: Concatenation software for the last assembly of multi-gene datasets with character set and codon information. Cladistics 2011, 27, 171-180. [CrossRef] [PubMed]

40. Swofford, D.L. PAUP* Phylogenetic Analysis Using Parsimony, (*and Other Methods); Version 4.0 b10; Sinauer Associates: Sunderland, MA, USA, 2002.

41. Ronquist, F.; Huelsenbeck, J.P. MrBayes 3: Bayesian phylogenetic inference under mixed models. Bioinformatics 2003, 19, 1572-1574. [CrossRef] [PubMed]

42. Kumar, S.; Stecher, G.; Tamura, K. MEGA7: Molecular Evolutionary Genetics Analysis version 7.0 for bigger datasets. Mol. Biol. Evol. 2016, 33, 1870-1874. [CrossRef] [PubMed]

43. Rodríguez, F.; Oliver, J.L.; Marín, A.; Medina, J.R. The general stochastic model of nucleotide substitutions. J. Theor. Biol. 1990, 142, 485-501. [CrossRef]

44. Page, R.D.M. TreeView: An application to display phylogenetic trees on personal computers. CABIOS 1996, 12, 357-358. [PubMed]

45. Fu, M.; Crous, P.W.; Bai, Q.; Zhang, P.F.; Xiang, J.; Guo, Y.S.; Zhao, F.F.; Yang, M.M.; Hong, N.; Xu, W.X.; et al. Colletotrichum species associated with anthracnose of Pyrus spp. in China. Persoonia 2019, 42, 1-35. [CrossRef]

46. Pinto, R. Melhoria das Técnicas Culturais na Produção de Mirtilo em Substrato. Master's Thesis, University of Lisbon, Lisbon, Portugal, 2015. Available online: https:/ / www.repository.utl.pt/bitstream/10400.5/11157/1/Tese\%20Rita\%20Pinto.pdf (accessed on 21 February 2021).

47. Baker, J.B.; Hancock, J.F.; Ramsdell, D.C. Screening highbush blueberry cultivars for resistance to Phomopsis canker. HortScience 1995, 30, 586-588. [CrossRef]

48. R Core Team. R: A Language and Environment for Statistical Computing; R Foundation for Statistical Computing: Vienna, Austria. Available online: https:/ / www.R-project.org/ (accessed on 14 February 2021).

49. Wickham, H. ggplot2: Elegant Graphics for Data Analysis, 2nd ed.; Springer: New York, NY, USA, 2016 ; p. 268.

50. Farr, D.F.; Rossman, A.Y. Fungal Databases, U.S. National Fungus Collections, ARS, USDA. Available online: https://nt.ars-grin. gov/fungaldatabases / (accessed on 10 May 2021).

51. Smit, W.A.; Wingfield, M.J.; Wingfield, B.D. A new canker disease of apple, pear, and plum rootstocks caused by Diaporthe ambigua in South Africa. Plant Dis. 1996, 80, 1331-1335. [CrossRef]

52. Hilário, S.; Santos, L.; Alves, A. Diaporthe amygdali, a species complex or a complex species? Fungal Biol. 2021, 125, 505-518. [CrossRef] [PubMed] 
53. Lopes, A.F.; Batista, E.; Hilário, S.; Santos, L.; Alves, A. Occurrence of Diaporthe species in Eucalyptus globulus, Pinus pinaster and Quercus suber in Portugal. For. Pathol. 2021, 51, e12674. [CrossRef]

54. Udayanga, D.; Castlebury, L.A.; Rossman, A.; Hyde, K.D. Species limits in Diaporthe: A molecular reassessment of D. citri, D. cytosporella, D. foeniculina and D. rudis. Persoonia 2014, 32, 83-101. [CrossRef]

55. Dissanayake, A.J.; Camporesi, E.; Hyde, K.D.; Wei, Z.; Yan, J.Y.; Li, X.H. Molecular phylogenetic analysis reveals seven new Diaporthe species from Italy. Mycosphere 2017, 8, 853-877. [CrossRef]

56. Crous, P.W.; Summerell, B.A.; Swart, L.; Denman, S.; Taylor, J.E.; Bezuidenhout, C.M.; Palm, M.E.; Marincowitz, S. Fungal pathogens of Proteaceae. Persoonia 2011, 27, 20-45. [CrossRef] [PubMed]

57. Santos, L.; Phillips, A.J.L.; Crous, P.W.; Alves, A. Diaporthe species on Rosaceae with descriptions of D. pyracanthae sp. Mycosphere 2017, 8, 485-511. [CrossRef]

58. Hilário, S.; Santos, L.; Phillips, A.J.L.; Alves, A. Caveats of the internal transcribed spacer region as a barcode to resolve species boundaries in Diaporthe. Fungal Biol. 2021, in press. [CrossRef]

59. Guarnaccia, V.; Crous, P.W. Species of Diaporthe on Camellia and Citrus in the Azores Islands. Phytopathol. Mediterr. 2018, 57, 307-319.

60. Mostert, L.; Crous, P.W.; Kang, J.C.; Phillips, A.J.L. Species of Phomopsis and a Libertella sp. occurring on grapevines with specific reference to South Africa: Morphological, cultural, molecular and pathological characterization. Mycologia 2001, 93, 146-167. [CrossRef]

61. Van Niekerk, J.M.; Groenewald, J.Z.; Farr, D.F.; Fourie, P.H.; Halleen, F.; Crous, P.W. Reassessment of Phomopsis species on grapevines. Australas. Plant Pathol. 2005, 34, 27-39. [CrossRef]

62. Van Rensburg, J.C.J.; Lamprecht, S.C.; Groenewald, J.Z.; Castlebury, L.A.; Crous, P.W. Characterisation of Phomopsis spp. associated with die-back of rooibos (Aspalathus linearis) in South Africa. Stud. Mycol. 2006, 55, 65-74. [CrossRef] [PubMed]

63. Diogo, E.L.F.; Santos, J.M.; Phillips, A.J.L. Phylogeny, morphology and pathogenicity of Diaporthe and Phomopsis species on almond in Portugal. Fungal Divers. 2010, 44, 107-115. [CrossRef]

64. Urbez-Torres, J.R.; Peduto, F.; Smith, R.J.; Gubler, W.D. Phomopsis dieback, a grapevine trunk disease caused by Phomopsis viticola in California. Plant Dis. 2013, 97, 1571-1579. [CrossRef] [PubMed]

65. Thomidis, T.; Prodromou, I.; Zambounis, A. Occurrence of Diaporthe ambigua Nitschke causing postharvest fruit rot on kiwifruit in Chrysoupoli Kavala, Greece. J. Plant Pathol. 2019, 101, 1295-1296. [CrossRef]

66. Spies, C.F.J.; Mostert, L.; Carlucci, A.; Moyo, P.; Van Jaarsveld, W.J.; du Plessis, I.L.; van Dyk, M.; Halleen, F. Dieback and decline pathogens of olive trees in South Africa. Persoonia 2020, 45, 196-220. [CrossRef]

67. Udayanga, D.; Liu, X.; Crous, P.W.; McKenzie, E.H.; Chukeatirote, E.; Hyde, K.D. A multi-locus phylogenetic evaluation of Diaporthe (Phomopsis). Fungal Divers. 2012, 56, 157-171. [CrossRef]

68. Möller, M.; Stukenbrock, E.H. Evolution and genome architecture in fungal plant pathogens. Nat. Rev. Microbiol. 2017, 15, 756-771. [CrossRef] [PubMed]

69. EPPO. European and Mediterranean Plant Protection Organization. EPPO A2 List of Pests Recommended for Regulation as Quarantine Pests. Available online: https:/ / www.eppo.int/ACTIVITIES/plant_quarantine/A2_list (accessed on 30 May 2021).

70. Jeger, M.; Bragard, C.; Caffier, D.; Candresse, T.; Chatzivassiliou, E.; Dehnen-Schmutz, K.; Gilioli, G.; Grégoire, J.C.; Miret, J.; MacLeod, A.; et al. Pest risk assessment of Diaporthe vaccinii for the EU territory. EFSA 2017, 15, 1-185.

71. Espinoza, J.G.; Briceño, E.X.; Keith, L.M.; Latorre, B.A. Canker and twig dieback of blueberry caused by Pestalotiopsis spp. and a Truncatella sp. in Chile. Plant Dis. 2008, 92, 1407-1414. [CrossRef]

72. Espinoza, J.G.; Briceño, E.X.; Chávez, E.R.; Úrbez-Torres, J.R.; Latorre, B.A. Neofusicoccum spp. associated with stem canker and dieback of blueberry in Chile. Plant Dis. 2009, 93, 1187-1194. [CrossRef]

73. Moral, J.; Agustí-Brisach, C.; Pérez-Rodríguez, M.; Xaviér, C.; Raya, M.C.; Rhouma, A.; Trapero, A. Identification of fungal species associated with branch dieback of olive and resistance of table cultivars to Neofusicoccum mediterraneum and Botryosphaeria dothidea. Plant Dis. 2017, 101, 306-316. [CrossRef] [PubMed]

74. Lorenzini, M.; Zapparoli, G. Diaporthe rudis associated with berry rot of postharvest grapes in Italy. Plant Dis. 2019, 103, 1030. [CrossRef] 